\title{
Calibration of models for pile settlement analysis using 64 field load tests
}

\author{
L.M. Zhang, Y. Xu, and W.H. Tang
}

\begin{abstract}
Due to the presence of uncertainties, errors inevitably arise with the estimations of pile settlement. To properly consider serviceability requirements in limit state design, it is necessary to characterize the performance of commonly used settlement prediction models. In this work, information from 64 cases of long driven steel H-piles from field static loading tests in Hong Kong is utilized to evaluate the errors of three settlement prediction models for single piles: two elastic methods and a nonlinear load-transfer method. Commonly adopted soil parameters recommended in two Hong Kong design guidelines are used to reflect the uncertainty arising from evaluation of soil properties. The model error is represented by a bias factor. A conventional statistical analysis was first conducted to study the variability of model bias. A regression analysis method was then proposed as a supplemental analysis of model bias when only limited test data were available or when the measured settlement data distribute in a large range. Both methods result in very similar mean biases. The mean bias of each prediction model tends to vary with the load level and the bearing stratum at the pile toe; while the coefficient of variation of model bias only varies in narrow ranges.
\end{abstract}

Key words: driven piles, limit state design, model calibration, pile foundations, settlement analysis, serviceability.

Résumé : À cause de la présence d'incertitudes, des erreurs se produisent inévitablement dans les estimations du tassement des pieux. Pour prendre en considération correctement les exigences de résistance dans la conception à l'état limite, il est nécessaire de caractériser la performance des modèles de prédiction de tassement utilisés communément. Dans ce travail, on utilise les informations d'essais de chargement statique faits sur le terrain à Hong Kong sur 64 cas de longs pieux $\mathrm{H}$ en acier foncés pour évaluer les erreurs de trois modèles de prédiction de tassement pour des pieux simples : deux méthodes élastiques et une méthode non linéaire de transfert de charge. On utilise les paramètres de sol communément adoptés et recommandés dans deux guides de conception de Hong Kong pour refléter l'incertitude provenant de l'évaluation des propriétés des sols. L'erreur du modèle est représentée par un facteur de différence systématique du modèle. On a réalisé en premier lieu une analyse statistique conventionnelle pour étudier la variabilité de la différence systématique du modèle. On a alors proposé une méthode d'analyse de régression comme analyse supplémentaire de la différence systématique du modèle lorsque seulement un nombre limité de données d'essai étaient disponibles ou lorsque les données de tassement mesuré se répartissaient sur une large plage. Les deux méthodes donnent des différences systématiques moyennes très semblables. La différence systématique moyenne de chaque modèle de prédiction a tendance à varier avec le niveau de charge et la strate portante à la pointe du pieu; alors que le coefficient de variation de la différence systématique du modèle ne varie que dans des plages étroites.

Mots-clés : pieux foncés, conception à l'état limite, calibrage de modèle, fondations sur pieux, analyse de tassement, utilité.

[Traduit par la Rédaction]

\section{Introduction}

A number of methods have been used to estimate pile settlement. Due to the presence of uncertainties, errors inevitably arise with the estimations. Two primary sources of error can be distinguished: those arising from the evaluation of input design parameters, such as soil properties, and those arising from geotechnical calculation models. Phoon and Kulhawy (1999), Baecher and Christian (2003), Zhang et al. (2004), Fenton and Griffiths (2005), Fenton et al. (2005) and many others have studied the sources of uncertainty from

Received 26 May 2006. Accepted 23 May 2007. Published on the NRC Research Press Web site at cgj.nrc.ca on 15 February 2008.

L.M. Zhang, ${ }^{1}$ Y. Xu, and W.H. Tang. Department of Civil Engineering, The Hong Kong University of Science and Technology, Clear Water Bay, Kowloon, Hong Kong.

${ }^{1}$ Corresponding author (e-mail: cezhangl@ust.hk). the evaluation of soil properties. Even if input design parameters have been estimated correctly, the prediction from a geotechnical calculation model is still expected to deviate from reality due to the systematic errors associated with the model itself (Der Kiureghian 1990; Phoon and Kulhawy 2005). The model errors may be from insufficient representation of the constitutive behavior of materials, simplification of boundary conditions, use of empirical assumptions, and numerical errors.

To develop limit-state design codes, models for both ultimate and serviceability limit states need to be calibrated (e.g., Becker 1996a, 1996b). Many models for pile-capacity prediction have been calibrated (e.g., Briaud and Tucker 1988; Paikowsky 2002; Zhang et al. 2001, 2005; Phoon and Kulhawy 2005). Yet the evaluation of models for pilemovement prediction has not received the same level of attention. Several investigators conducted surveys of model errors associated with settlement prediction. Briaud and Tucker (1988) evaluated five load-transfer methods for 
predicting the single pile settlement based on a 98 pile load test database obtained from the Mississippi State Highway Department. The piles included 64 square concrete piles, $27 \mathrm{H}$-piles, and 7 drilled shafts. The pile lengths were 3$25 \mathrm{~m}$, with an average of $12.2 \mathrm{~m}$. The accuracy of each method was quantified statistically at one half of the ultimate load. The American Society of Civil Engineers (ASCE) held a pile prediction symposium at Northwestern University to compare the predicted and observed axial behaviors of piles including the load-settlement response (Finno et al. 1989). Paikowsky and $\mathrm{Lu}$ (2006) discussed the uncertainties of several analysis methods for calculating deep foundation displacements. In general, pile settlement predictions were widely scattered, but few attempts have been made to calibrate commonly used prediction models.

Ideally, errors in input parameters and models should be calibrated separately. In this paper, since a standard procedure is followed to determine input parameters, the "model error" is broadly taken as the lumped error caused by both input parameters and prediction models. The model error is represented by a bias factor, $\lambda$, which is the ratio of the measured settlement, $S_{\mathrm{m}}$, to the predicted settlement, $S_{\mathrm{p}}$ (Shahin et al. 2005)

$$
\text { [1] } \lambda=\frac{S_{\mathrm{m}}}{S_{\mathrm{p}}}
$$

Model errors are often evaluated based on field or model tests. In this study, performance data from 64 cases of very long driven steel H-piles from field static loading tests in Hong Kong are utilized to evaluate model errors. These test piles were constructed in weathered soils that are commonly encountered in Hong Kong, Mainland China, and many southeast Asian countries. Three typical settlement prediction models for single piles are calibrated: two elastic methods and a nonlinear load-transfer method. Commonly adopted soil parameters recommended in two Hong Kong design guidelines (GEO 1993, 2006) are used to reflect the uncertainty arising from the evaluation of soil properties. The mean model bias and the coefficient of variation (COV) under a particular load (the intended design load or twice the design load) are established through a statistical analysis. Furthermore, a regression analysis is proposed to study the model bias at various load levels, particularly for the failure load at which limited test data are available.

\section{Field static loading tests on driven piles}

A database of dynamic and static tests conducted on steel H-piles in Hong Kong, the Hong Kong Driven Pile Database, was established (Zhang et al. 2006). In this study, the information from 64 cases of field static loading tests conducted in the past decade in five sites was selected for model calibration. Table 1 shows the general information from these load tests. The pile toe was driven to slightly (grade II) to completely (grade V) decomposed rocks. The corresponding penetration lengths of the test piles varied from 21.6 to $78 \mathrm{~m}$ with an average of $45.7 \mathrm{~m}$. Two sizes of steel $\mathrm{H}$-piles were used in the field tests: $305 \mathrm{~mm} \times 305 \mathrm{~mm} \times 180 \mathrm{~kg} / \mathrm{m}$ piles (15 cases) and $305 \mathrm{~mm} \times 305 \mathrm{~mm} \times 223 \mathrm{~kg} / \mathrm{m}$ piles (49 cases). Detailed properties of the pile sections are summarized in Table 2.
Within the 64 test cases, 33 were conducted on working piles and 31 were conducted on preliminary piles (Table 1). Two and three load cycles were applied on working piles and preliminary piles, respectively, following the load-test procedures outlined by Hong Kong Housing Authority (2000) or Buildings Department (2000). For working piles, the peak loads of the two load cycles corresponded to one times $(1 \times)$ and twice $(2 \times)$ the design compression capacity of the pile (intended design load), respectively, which were $2950 \mathrm{kN}$ for $305 \mathrm{~mm} \times 305 \mathrm{~mm} \times 180 \mathrm{~kg} / \mathrm{m}$ piles and 3548 $\mathrm{kN}$ for $305 \mathrm{~mm} \times 305 \mathrm{~mm} \times 223 \mathrm{~kg} / \mathrm{m}$ piles. For preliminary piles, in addition to the intended design load and twice the design load, the piles were loaded to failure in terms of either the geotechnical capacity or the structural capacity. In this work, the failure load is cut off at three times the design load if it is larger than three times the design load. A typical load-settlement curve involving three load cycles from a load test and the corresponding simplified virgin load curve are shown in Fig. 1. Figure 2 presents the simplified loadsettlement curves for the 64 load tests.

\section{Models for settlement analysis}

A number of settlement analysis methods for single piles are available. These methods may be broadly classified into three categories: elastic continuum methods, load-transfer methods, and numerical methods (GEO 2006). Examples of such methods are the elastic methods proposed by Vesic (1977) and Poulos and Davis (1980), the simplified elastic methods proposed by Randolph and Wroth (1978) and Fleming et al. (1992), the nonlinear load-transfer methods proposed by Coyle and Reese (1966) and McVay et al. (1989), and the numerical methods based on advanced constitutive models of soil behavior proposed by Jardine et al. (1986). In this paper, three representative methods are adopted for the calibration exercise: the elastic method proposed by Vesic (1977), the simplified analysis method proposed by Fleming et al. (1992), and a nonlinear load-transfer method (McVay et al. 1989) implemented in program FB-Pier (BSI 2003).

In Vesic's method, the settlement of a pile under vertical loading, $S$, includes three components

$$
\text { [2] } \quad S=S_{1}+S_{2}+S_{3}
$$

where $S_{1}$ is the elastic pile compression; $S_{2}$ is the pile settlement caused by the load at the pile toe; and $S_{3}$ is the pile settlement caused by the load transmitted along the pile shaft. If the pile material is assumed to be elastic, the elastic pile compression can be calculated by

[3] $\quad S_{1}=\frac{\left(Q_{\mathrm{b}}+\xi Q_{\mathrm{s}}\right) L}{A_{\mathrm{p}} E_{\mathrm{p}}}$

where $Q_{\mathrm{b}}$ and $Q_{\mathrm{s}}$ are the loads carried by the pile toe and pile shaft, respectively; $A_{\mathrm{p}}$ is the pile cross-section area; $L$ is the pile length; $E_{\mathrm{p}}$ is the modulus of elasticity of the pile material; and $\xi$ is a coefficient depending on the nature of unit friction resistance distribution along the pile shaft. In this work, the distribution is assumed to be uniform and hence $\xi=0.5$. Settlement $S_{2}$ may be expressed in a form similar to that for a shallow foundation 
Table 1. General information from 64 tests on long driven piles.

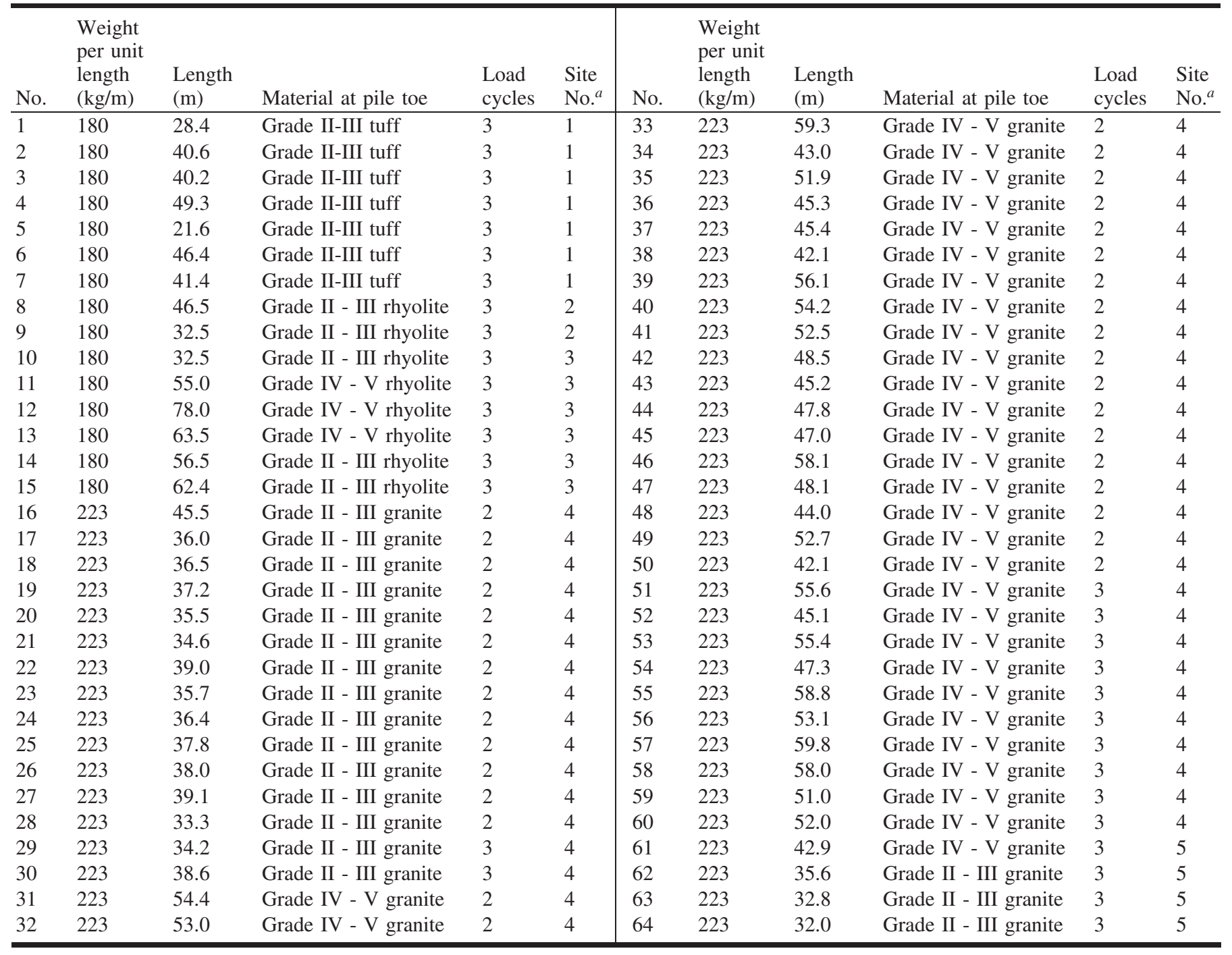

${ }^{a}$ 1, Tseung Kwan O; 2, Tuen Mun; 3, Tung Chung; 4, South East Kowloon; 5, Un Chau Street.

Table 2. Detailed information on $305 \mathrm{~mm} \times 305 \mathrm{~mm} \times 180 \mathrm{~kg} / \mathrm{m}$ and $305 \mathrm{~mm} \times 305 \mathrm{~mm} \times$ $223 \mathrm{~kg} / \mathrm{m}$ steel H-piles.

\begin{tabular}{lll}
\hline & Pile size & \\
\cline { 2 - 3 } & $305 \mathrm{~mm} \times 305 \mathrm{~mm} \times 180 \mathrm{~kg} / \mathrm{m}$ & $305 \mathrm{~mm} \times 305 \mathrm{~mm} \times 223 \mathrm{~kg} / \mathrm{m}$ \\
\hline Young's modulus $(\mathrm{MPa})$ & 205000 & 205000 \\
Poisson's ratio & 0.3 & 0.3 \\
Shear modulus $(\mathrm{MPa})$ & 78846 & 78846 \\
Cross sectional area $\left(\mathrm{m}^{2}\right)$ & 0.0229 & 0.0285 \\
Width $(\mathrm{m})$ & 0.3197 & 0.3257 \\
Depth $(\mathrm{m})$ & 0.3267 & 0.3379 \\
Area of pile base $\left(\mathrm{m}^{2}\right)$ & 0.1044 & 0.1101 \\
Web thickness $(\mathrm{m})$ & 0.0248 & 0.0303 \\
Flange thickness $(\mathrm{m})$ & 0.0248 & 0.0304 \\
Inertial 2-axis $\left(\mathrm{m}^{4}\right)$ & 0.00041 & 0.00053 \\
Inertial 3-axis $\left(\mathrm{m}^{4}\right)$ & 0.00014 & 0.00018 \\
Torsional inertial $\left(\mathrm{m}^{4}\right)$ & 0.00000555 & 0.00001037 \\
\hline
\end{tabular}


Fig. 1. Typical load-settlement curve involving three loading cycles from a field load test and the corresponding simplified virgin load curve.

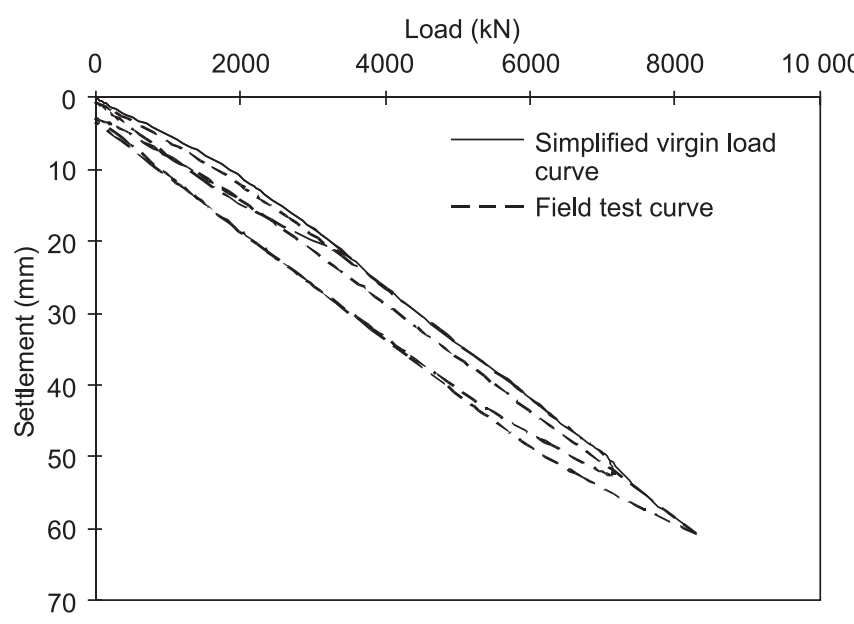

Fig. 2. Load-settlement curves from 64 field load tests.
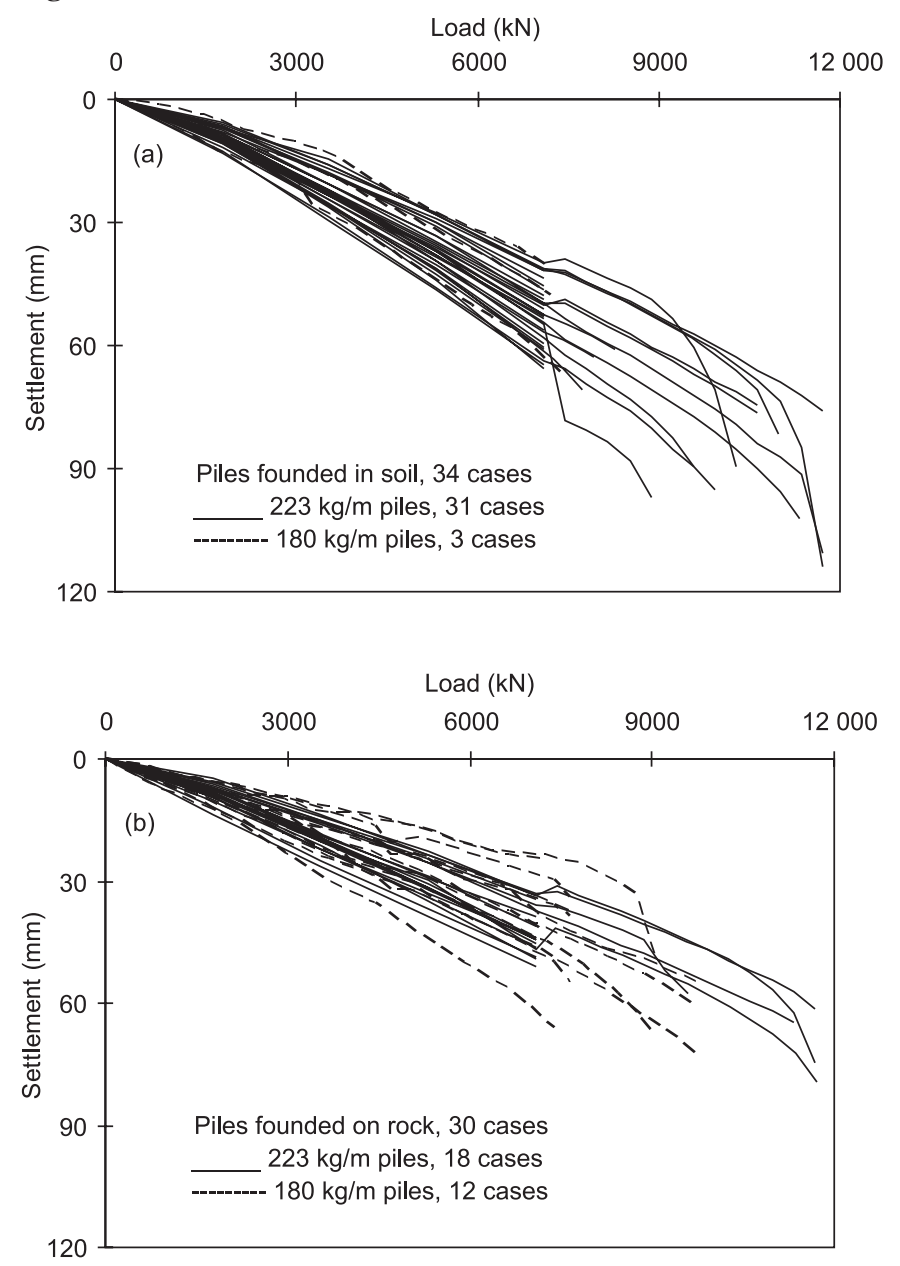

[4] $\quad S_{2}=\frac{q_{\mathrm{b}} D}{E_{\mathrm{sb}}}\left(1-\nu^{2}\right) I_{\mathrm{b}}$

where $D$ is the pile width or diameter; $q_{\mathrm{b}}$ is the load per unit area at the pile toe, $q_{\mathrm{b}}=Q_{\mathrm{b}} / A_{\mathrm{b}} ; A_{\mathrm{b}}$ is the pile base area; $E_{\mathrm{sb}}$ is the modulus of elasticity of the soil at the pile toe; $\nu$ is
Poisson's ratio; and $I_{\mathrm{b}}$ is an influence factor, generally $I_{\mathrm{b}}=$ 0.85 . Finally, $S_{3}$ is given as

[5] $\quad S_{3}=\left(\frac{Q_{\mathrm{s}}}{p L}\right) \frac{D}{E_{\mathrm{ss}}}\left(1-\nu^{2}\right) I_{\mathrm{s}}$

where $p$ is the pile perimeter; $E_{\mathrm{ss}}$ is the modulus of elasticity of the soil along the pile shaft; and $I_{\mathrm{s}}$ is an influence factor. The influence factor $I_{\mathrm{s}}$ can be calculated by an empirical relation (Vesic 1977)

[6] $\quad I_{\mathrm{s}}=2+0.35 \sqrt{\frac{L}{D}}$

With Vesic's method, both $Q_{\mathrm{b}}$ and $Q_{\mathrm{s}}$ are required. In this work, $Q_{\mathrm{b}}$ and $Q_{\mathrm{s}}$ are obtained using two methods. In the first method (Vesic's method I), these two loads are determined from a nonlinear load-transfer method, which will be introduced later. In the second method (Vesic's method II), these two loads are determined using empirical ratios of $Q_{\mathrm{b}}$ to the total load applied on pile $Q$ based on field test data. Shek (2005) reported load-transfer in 14 test piles, including 11 piles founded in soil and 3 piles founded on rock. The mean ratios of $Q_{b} / Q$ for the piles founded in soil and the piles founded on rock are summarized in Table 3 and applied in this calibration exercise. The mean values of $Q_{\mathrm{b}} / Q$ at twice the design load and the failure load are very similar. Hence, the average of the mean values is adopted for calibration at both twice the design load and the failure load.

In the Fleming et al. method, the settlement of a pile is given by the following approximate closed-form solution (Fleming et al. 1992):

$$
\frac{Q}{G_{\mathrm{L}} r_{0} S}=\frac{\frac{4 \eta}{(1-\nu) \xi_{G}}+\frac{2 \pi \rho}{\zeta} \frac{\tanh (\mu L)}{\mu L} \frac{L}{r_{0}}}{1+\frac{4 \eta}{\pi \lambda_{\mathrm{p}}(1-\nu) \xi_{G}} \frac{\tanh (\mu L)}{\mu L} \frac{L}{r_{0}}}
$$

where $\eta=r_{\mathrm{b}} / r_{0}, r_{0}$ and $r_{\mathrm{b}}$ are the radii of the pile shaft and pile toe, respectively (for H-piles, $\pi r_{0}^{2}=\pi r_{\mathrm{b}}^{2}=D h, h$ is the depth of the pile cross-section); $\xi_{\mathrm{G}}=G_{\mathrm{L}} / G_{\mathrm{b}}, G_{\mathrm{L}}$ is the shear modulus of the soil at depth $L$, and $G_{\mathrm{b}}$ is the shear modulus of the soil beneath the pile toe; $\rho=G_{\text {ave }} / G_{\mathrm{L}}, G_{\text {ave }}$ is the average shear modulus of the soil along the pile shaft; $\lambda_{\mathrm{p}}$ is the pile stiffness ratio, $\lambda_{\mathrm{p}}=E_{\mathrm{p}} / G_{\mathrm{L}} ; \zeta=\ln \{[0.25+(2.5 \rho(1-\nu)-$ $\left.\left.0.25) \xi_{\mathrm{G}}\right] L / r_{0}\right\} ; \mu L=(2 / \zeta \lambda)^{1 / 2}\left(L / r_{0}\right)$. If the slenderness ratio $L / r_{0}$ is less than $0.5 \lambda_{p}{ }^{1 / 2}$, the pile may be treated as effectively rigid and eq. [7] then reduces to

[8] $\quad \frac{Q}{G_{\mathrm{L}} r_{0} S}=\frac{4 \eta}{(1-\nu) \xi_{\mathrm{G}}}+\frac{2 \pi \rho L}{r_{0}}$

If the slenderness ratio $L / r_{0}$ is larger than $3 \lambda_{p}{ }^{1 / 2}$, the pile may be treated as infinitely long, and eq. [7] then reduces to

[9] $\frac{Q}{G_{\mathrm{L}}^{\prime} r_{0} S}=\pi \rho\left(\frac{2 \lambda_{\mathrm{p}}}{\zeta}\right)^{1 / 2}$

In this case, $G_{\mathrm{L}}{ }^{\prime}$ is the soil shear modulus at the bottom of the active pile length $L_{\mathrm{ac}}$, where $L_{\mathrm{ac}}=3 r_{0} \lambda_{\mathrm{p}}{ }^{1 / 2}$.

In the nonlinear load-transfer method implemented in FBPier, the axial $\tau-Z$ curve for modeling the pile-soil interaction along the pile is given as (McVay et al. 1989) 
Table 3. Empirical ratios of $Q_{\mathrm{b}}$ to total load $Q$ based on field static loading tests.

\begin{tabular}{lll}
\hline & $\begin{array}{l}\text { At the intended } \\
\text { design load }\end{array}$ & $\begin{array}{l}\text { At twice the } \\
\text { design load or } \\
\text { the failure load }\end{array}$ \\
\hline Piles founded in soil & 0.19 & 0.32 \\
Piles founded on rock & 0.53 & 0.63 \\
\hline
\end{tabular}

$$
Z=\frac{\tau_{0} r_{0}}{G_{\text {is }}}\left[\ln \frac{\left(r_{\mathrm{m}}-\beta\right)}{\left(r_{0}-\beta\right)}+\frac{\beta\left(r_{\mathrm{m}}-r_{0}\right)}{\left(r_{\mathrm{m}}-\beta\right)\left(r_{0}-\beta\right)}\right]
$$

where $\beta=r_{0} \tau_{0} / \tau_{\mathrm{f}}, \tau_{0}$ is the shear stress being transferred to the soil for a given settlement $Z ; \tau_{\mathrm{f}}$ is the ultimate shear stress transferred to the soil; $r_{\mathrm{m}}$ is the radius out from the pile shaft where axial loading effects on soil are negligible, assumed to be the pile length times (one minus the soil's Poisson's ratio) times the ratio of the soil's shear modulus at the pile center to the value at the pile toe; $G_{\text {is }}$ is the initial shear modulus of the soil along the pile shaft. The nonlinear $Q-Z$ relationship for the pile toe is given as (McVay et al. 1989)

$$
\text { [11] } Z=\frac{Q_{\mathrm{b}}(1-\nu)}{4 r_{0} G_{\mathrm{ib}}\left[1-\frac{Q_{\mathrm{b}}}{Q_{\mathrm{f}}}\right]^{2}}
$$

where $Q_{\mathrm{f}}$ is the ultimate toe resistance and $G_{\mathrm{ib}}$ is the initial shear modulus of the soil at the pile toe.

\section{Soil parameters}

Most of the 64 test piles were constructed in reclaimed grounds. Before evaluating input soil parameters, the borehole records for the field tests are introduced briefly using a typical borehole record shown in Fig. 3. The primary information in Fig. 3 includes water level, blow count " $N$ " from the standard penetration test (SPT), weathering grade, and detailed soil description. According to the borehole record, the ground profile can be simplified as four successive strata: fill, marine deposits (not present in some cases), alluvium, and finally, decomposed rock. Each layer is assumed to be homogeneous and isotropic sandy soil, because sand or silt consists of the majority of these strata. The pile toe was driven to the decomposed rock. A weathering grade system (GEO 2006) was used to determine whether the decomposed rock material is considered to be soil (grade IV or V) or rock (grade II or III). Ultimately, the ground profile is simplified for analysis as shown on the right side of Fig. 3. Based on the pile toe soil or rock conditions, the 64 pile cases are further divided into two groups: 34 cases of piles founded in soil (20 working piles and 14 preliminary piles) and 30 cases founded on rock (13 working piles and 17 preliminary piles).

The basic soil parameters required for the three prediction models are summarized in Table 4. With Vesic's method, the soil parameters required are Poisson's ratio $\nu$ and Young's modulus $E_{\mathrm{s}}$. Poisson's ratio is assumed to be 0.3 , as commonly used in practice, and $E_{\mathrm{s}}$ can be estimated using an empirical correlation with the SPT " $N$ " value: $E_{s}=2 N \mathrm{MPa}$ (GEO 2006). According to the borehole records, the SPT " $N$ " values for fill, marine deposits, and alluvium are generally less than 50 while those for the completely decomposed rocks are often larger than 50. In this work, the SPT " $N$ " value is cut off at 500 if it is larger than 500. To be consistent with the practice in Hong Kong (GEO 2006), $E_{\mathrm{s}}$ is adjusted as $E_{\mathrm{s}}=1.7 N \mathrm{MPa}$ if the SPT " $N$ " value is less than 50 , and $E_{\mathrm{s}}=2 N \mathrm{MPa}$ if the SPT " $N$ " value is larger than 50 . The Young's modulus of the $i$ th soil layer $E_{\mathrm{s} i}$ is calculated using the average SPT " $N$ " value of this soil layer; and $E_{\mathrm{sb}}$ is calculated using the SPT " $N$ " value of the soil around the pile toe. Following Poulos and Davis (1980), the average Young's modulus of the soils along the pile shaft, $E_{\text {ave }}$, is calculated by

$$
E_{\mathrm{ave}}=\left(\frac{1}{L}\right) \sum_{i} E_{\mathrm{s} i} L_{i}
$$

where $L_{i}$ is the thickness of the $i$ th soil layer.

With Fleming et al.'s (1992) method, the following soil parameters are required: $G_{\mathrm{ave}}, G_{\mathrm{L}}$ and $G_{\mathrm{b}}$, and Poisson's ratio $\nu$. The value of $G_{\text {ave }}$ can be obtained using $\nu$ and $E_{\text {ave }}$, which can be obtained in the same way as in Vesic's method, and $G_{\mathrm{L}}=2 G_{\text {ave }}$ if the soil modulus is assumed to increase linearly with depth; $G_{\mathrm{b}}$ can be obtained using $\nu$ and $E_{\mathrm{sb}}$.

In the nonlinear load-transfer method implemented in FBPier, several inputs are required: water level $L_{\mathrm{w}}$, total unit weight $\gamma$, Poisson's ratio $\nu$, shear modulus $G$, internal friction angle $\phi$, ultimate shear stress transferred to the soil $\tau_{\mathrm{f}}$, and axial ultimate toe resistance $Q_{\mathrm{f}}$. Firstly, $L_{\mathrm{w}}$ is assumed to be the mean value from the borehole records, $L_{\mathrm{w}}=2 \mathrm{~m}$ for the convenience of computation. Secondly, as most of the ground is submerged and considered to be fully saturated, $\gamma$ is set to be the maximum of the typical values shown in Table 5 (GEO 1993), $\gamma=21 \mathrm{kN} / \mathrm{m}^{3}$ for all the strata. Thirdly, $G$ can be obtained using $\nu$ and $E_{\mathrm{s}}$, as in Vesic's method. Fourthly, $\phi$ can be determined using the empirical relationship with the SPT " $N$ " value shown in Fig. 4 (Schmertmann 1975; GEO 1993). The maximum $\phi$ is cut off at $44^{\circ}$ according to the ranges given in Table 5 (GEO 1993). Finally, $\tau_{\mathrm{f}}$ of a particular soil layer and $Q_{\mathrm{f}}$ are calculated using the following equations (GEO 2006):

$$
\begin{aligned}
& \tau_{\mathrm{f}}=K_{\mathrm{s}} \sigma_{\mathrm{ave}}^{\prime} \tan \delta_{\mathrm{s}} \\
& Q_{\mathrm{f}}=N_{\mathrm{q}} \sigma_{\mathrm{v} 0}^{\prime} A_{\mathrm{b}}
\end{aligned}
$$

where $K_{\mathrm{s}}$ is the coefficient of horizontal earth pressure on pile for the soil layer; $\sigma_{\text {ave }}^{\prime}$ is the average effective stress of the soil layer; $\delta_{\mathrm{s}}$ is the angle of friction at the pile-soil interface through the soil layer; $N_{\mathrm{q}}$ is a bearing capacity factor; and $\sigma_{\mathrm{v} 0}^{\prime}$ is the effective stress at pile toe. The values of $K_{\mathrm{s}}$, $\delta_{\mathrm{s}}$, and $N_{\mathrm{q}}$ can be determined by their relationships with $\phi$ : $K_{\mathrm{s}}=1.5(1-\sin \phi) ; \delta_{\mathrm{s}}=0.75 \phi$; and the Berezantzev et al. (1961) curve for $N_{\mathrm{q}}$ shown in Fig. 5. In this work, $N_{\mathrm{q}}$ is limited to an upper bound of 200 for the sake of safety.

Some test piles penetrated to the grade II or III rock layer, so pertinent parameters for the rocks at the pile toe should be used. The field unconfined compression strength of rock, $q_{\mathrm{uf}}$, is set to be $25 \mathrm{MPa}$, which is the minimum value for grade II or III rock (GEO 2006) and is similar to the minimum value of $28 \mathrm{MPa}$ obtained from the laboratory unconfined compression strength, $q_{\mathrm{ul}}$, of $140 \mathrm{MPa}$ considering scale effects recommended by Goodman (1980). For common Hong Kong rocks, the ratio of the laboratory modulus of deforma- 
Fig. 3. A typical borehole record and the simplified profile.

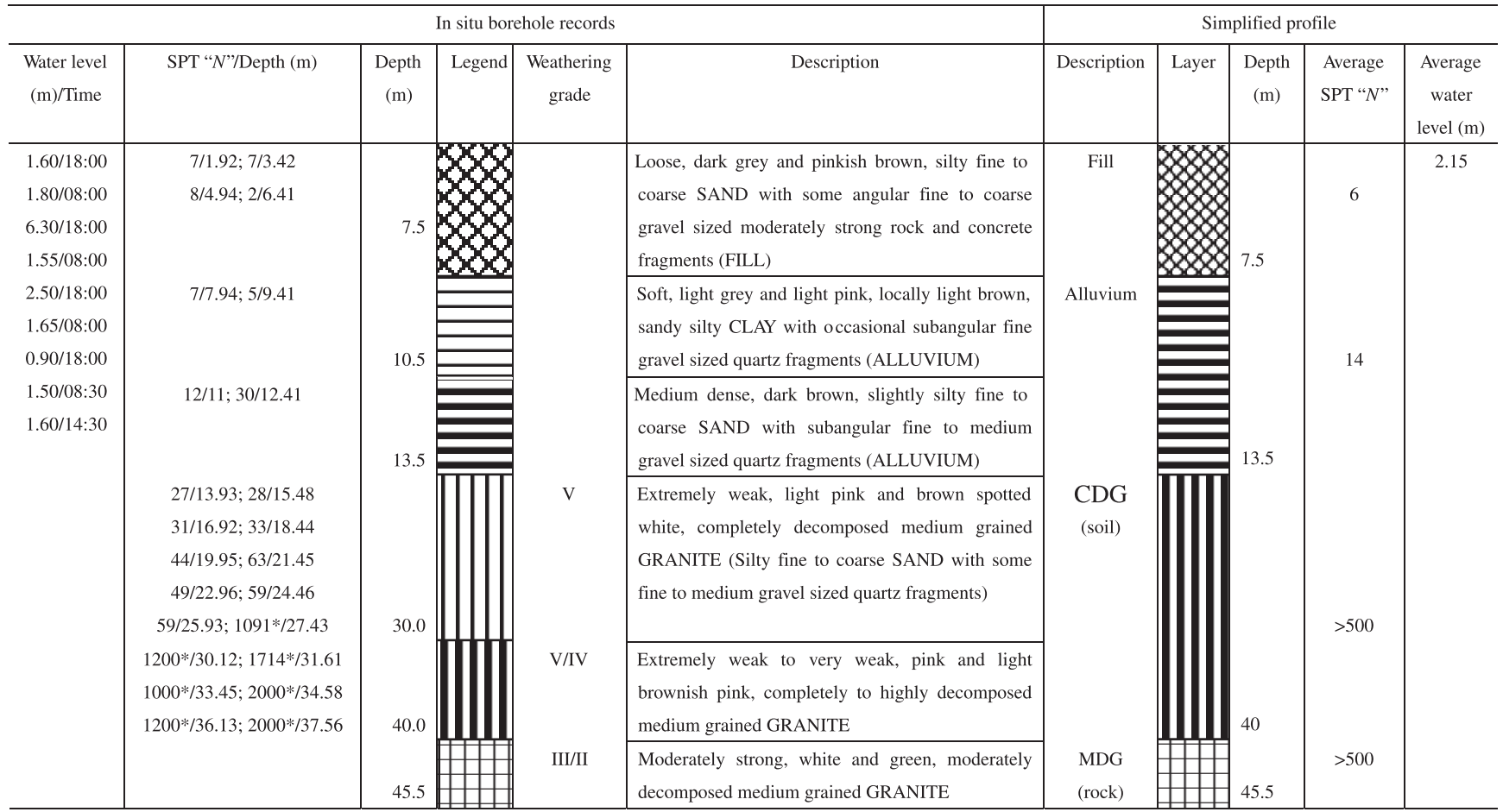

*Note: The SPT test is terminated when the blow count reaches 200 if the penetration is smaller than $300 \mathrm{~mm}$. For instance at depth $27.43 \mathrm{~m}$, the penetration is only $55 \mathrm{~mm}$ after 200 blows; the calculated blow count is then $N=200 / 55 \times 300=1091$

Table 4. Basic soil parameter requirements for the three settlement prediction models.

\begin{tabular}{|c|c|c|c|c|c|c|}
\hline & $\begin{array}{l}\text { Water } \\
\text { level, } L_{\mathrm{w}}\end{array}$ & $\begin{array}{l}\text { Total unit } \\
\text { weight, } \gamma\end{array}$ & $\begin{array}{l}\text { Young's } \\
\text { modulus, } E_{\mathrm{s}}\end{array}$ & $\begin{array}{l}\text { Poisson's } \\
\text { ratio, } \nu\end{array}$ & $\begin{array}{l}\text { Shear } \\
\text { modulus, } G\end{array}$ & $\begin{array}{l}\text { Internal } \\
\text { friction } \\
\text { angle, } \phi\end{array}$ \\
\hline Vesic's (1977) method & - & - & $\sqrt{ }$ & $\sqrt{ }$ & - & - \\
\hline Fleming et al.'s (1992) method & - & - & $\sqrt{ }$ & $\sqrt{ }$ & $\sqrt{ }$ & - \\
\hline Load-transfer method (McVay et al. 1989) & $\sqrt{ }$ & $\sqrt{ }$ & $\sqrt{ }$ & $\sqrt{ }$ & $\sqrt{ }$ & $\sqrt{ }$ \\
\hline
\end{tabular}

Table 5. Typical values of geotechnical parameters for selected Hong Kong soils (after GEO 1993).

\begin{tabular}{llllll}
\hline & $\begin{array}{l}\text { Bulk unit } \\
\text { weight, } \\
\gamma\left(\mathrm{kN} / \mathrm{m}^{3}\right)\end{array}$ & $\begin{array}{l}\text { Dry unit } \\
\text { weight, } \\
\gamma_{\mathrm{d}}\left(\mathrm{kN} / \mathrm{m}^{3}\right)\end{array}$ & $\begin{array}{l}\text { Shear strength parameters } \\
\text { Friction } \\
\text { angle, } \\
\phi^{\prime}\left({ }^{\circ}\right)\end{array}$ & $\begin{array}{l}\text { Cohesion, } \\
c^{\prime}(\mathrm{kPa})\end{array}$ & $\begin{array}{l}\text { Mass } \\
\text { permeability, } \\
k(\mathrm{~m} / \mathrm{s})\end{array}$ \\
\hline Compacted fill & & & & & \\
Completely decomposed granite & $19-21$ & $15-19$ & $38-42$ & $0-5$ & $10^{-6}-10^{-7}$ \\
Completely decomposed volcanic & $18-21$ & $15-19$ & $35-38$ & $0-5$ & $10^{-6}-10^{-8}$ \\
Crushed rock fill & $18-21$ & $18-21$ & $45->50$ & 0 & $>10^{-2}-10^{-4}$ \\
In situ soil & & & & & $10^{-5}-10^{-7}$ \\
Completely decomposed granite & $16-21$ & $14-19$ & $35-44$ & $5-15$ & $10^{-5}-10^{-7}$ \\
Completely decomposed volcanic & $16-21$ & $14-19$ & $32-38$ & $5-10$ & $10^{-4}-10^{-7}$ \\
Colluvium & $15-21$ & $13-19$ & $26-40$ & $0-10$ & 10 \\
\hline
\end{tabular}

tion of rock material, $E_{1}$, to $q_{\mathrm{ul}}$ generally lies between 200 and 500 (GEO 1993), and the mean value, 350, is adopted in this work. A mass factor, set to be 0.8 in this work (GEO 1993), is used to relate the field modulus of deformation of rock, $E_{\mathrm{f}}$, to $E_{\mathrm{l}}$. Then $E_{\mathrm{f}}$ is calculated as $39.2 \mathrm{GPa}$, similar to the minimum value of $38.6 \mathrm{GPa}$ proposed by Peck (1969). In addition, $\nu$ is assumed to be 0.26 , the mean of the typical values proposed by Peck (1969). The ultimate unit toe resistance on rock can be expressed as (Goodman 1980)

$$
q_{\mathrm{p}}=q_{\mathrm{uf}}\left(N_{\varphi}+1\right)
$$

where $N_{\varphi}=\tan ^{2}\left(45^{\circ}+\phi / 2\right)$. A safe $\phi$ of $44^{\circ}$, which is the same as the cut-off value adopted for soil, is assumed, re- 
Fig. 4. Empirical method for estimating $\phi$ of sand from SPT " $N$ " values (after Schmertmann 1975).

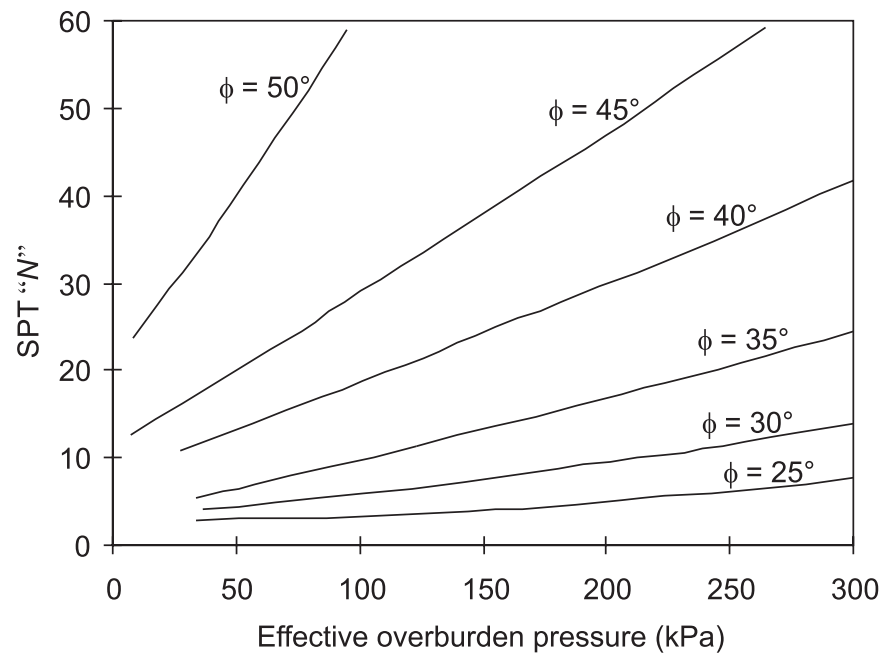

Fig. 5. Relationship between $N_{\mathrm{q}}$ and $\phi$ (after Berezantzev et al. 1961).

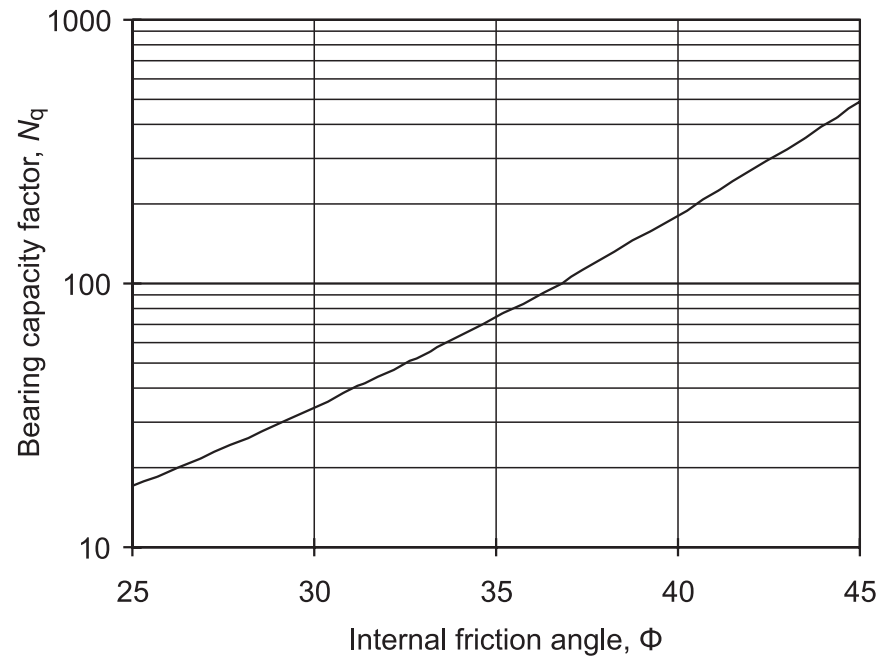

Fig. 6. Frequency diagrams of the model bias for piles founded in soil: $(a)$ with Vesic's method I at the intended design load; $(b)$ with Vesic's method I at twice the design load; $(c)$ with Vesic's method II at the intended design load; $(d)$ with Vesic's method II at twice the design load.
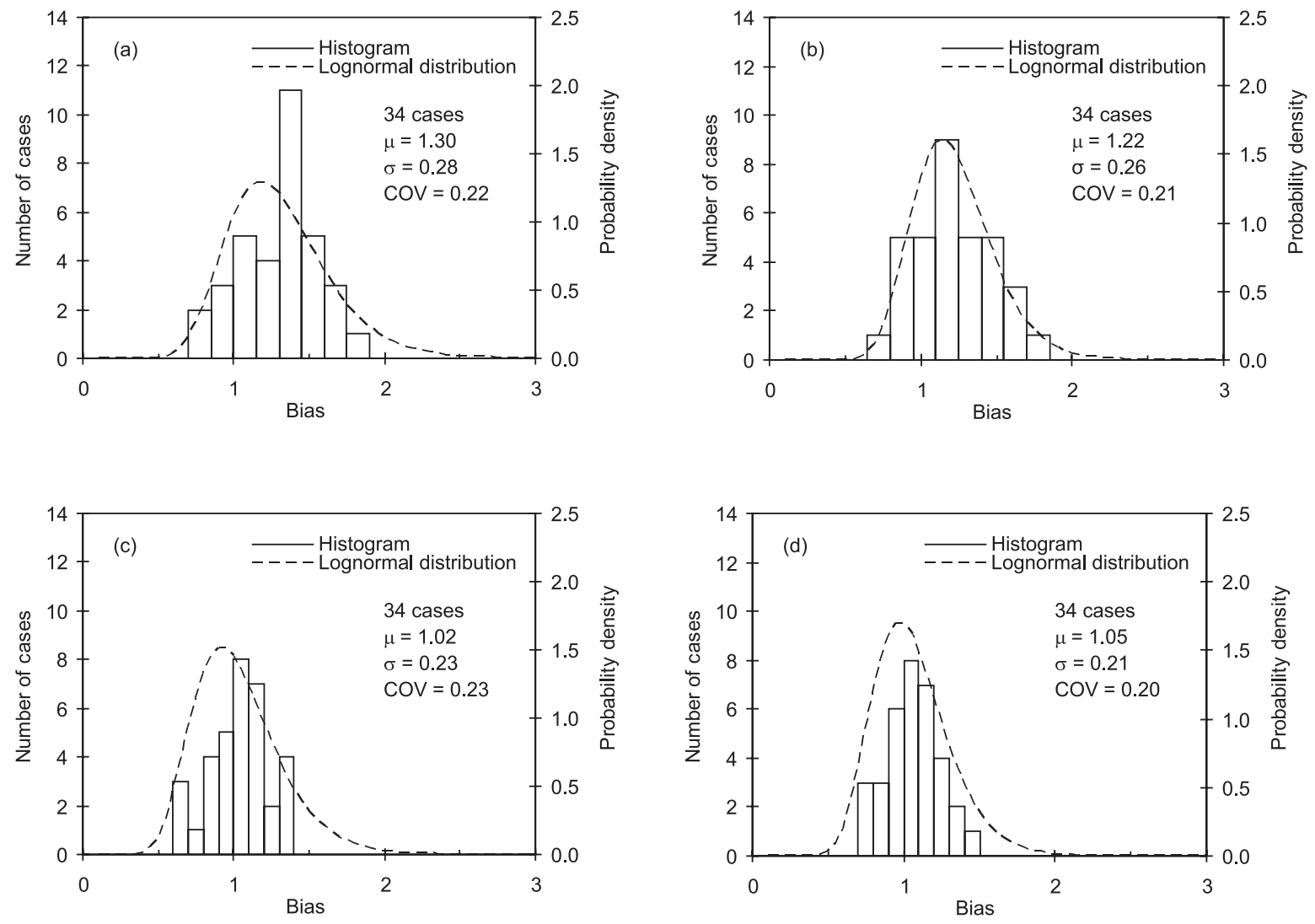

sulting in $N_{\varphi}=5.55$. The corresponding $q_{\mathrm{p}}$ from eq. [15] is $139 \mathrm{MPa}$.

\section{Statistical analysis of model uncertainty}

By comparing the predicted settlements using the three performance models against the respective measured settlements, the model biases can be calculated with eq. [1] and

used to estimate the probability density function (PDF) of $\lambda$. Due to the limited number of preliminary pile cases, the available data at the third load cycle are limited and hence no statistical analysis is conducted for the model bias at the failure load.

Figures 6-11 show the histograms of the model bias for all the samples for different prediction models (Vesic's method, Fleming et al.'s method, and the nonlinear load- 
Fig. 7. Frequency diagrams of the model bias for piles founded on rock: $(a)$ with Vesic's method I at the intended design load; $(b)$ with Vesic's method I at twice the design load; $(c)$ with Vesic's method II at the intended design load; $(d)$ with Vesic's method II at twice the design load.
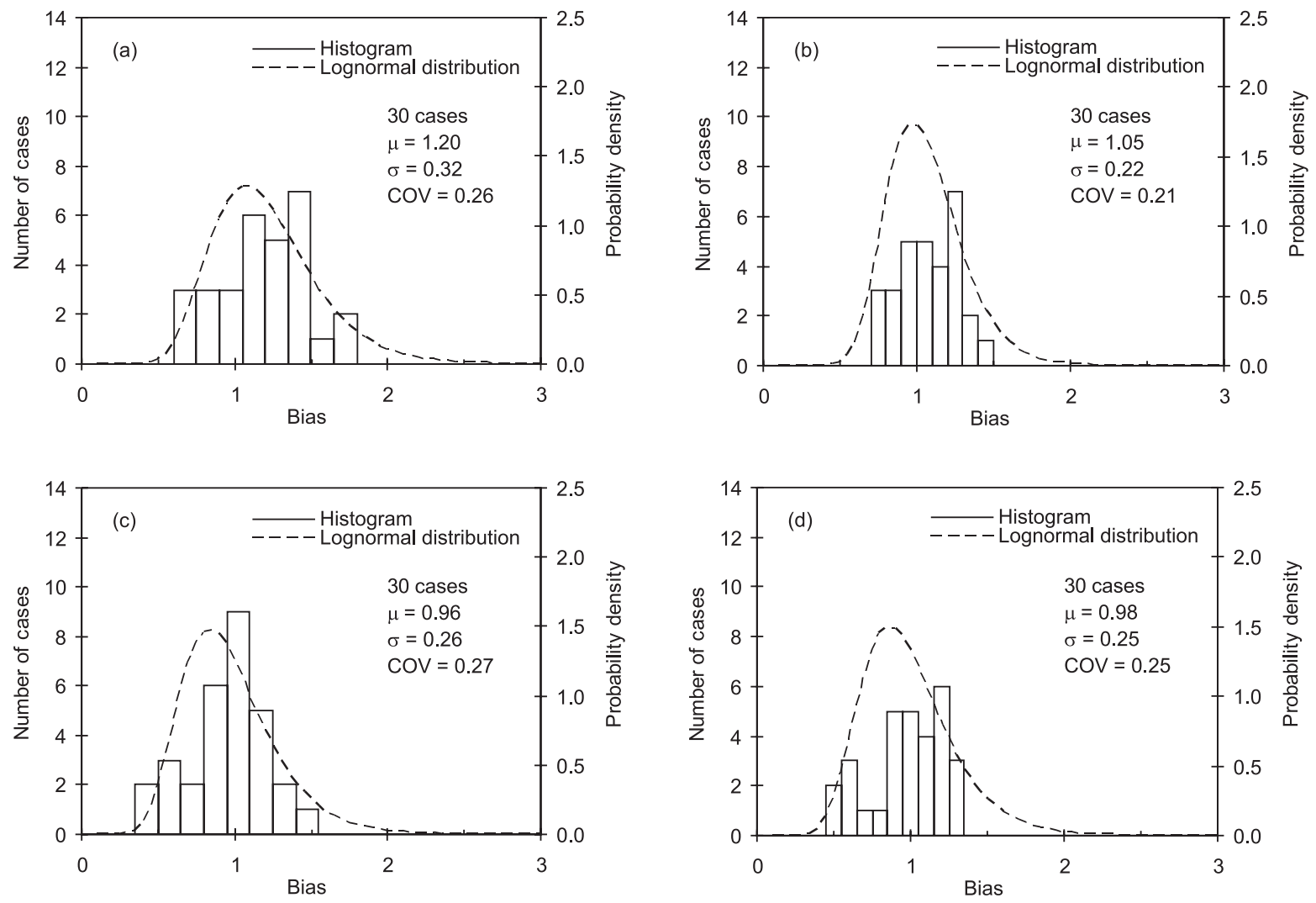

transfer method), load levels (the intended design load and twice the design load), and ground conditions (piles founded in soil and on rock). For compatibility with reliability analysis, it is convenient to assume that $\lambda$ follows a lognormal distribution. The validity of this distribution has been confirmed using the chi-square goodness-of-fit test (e.g., Ang and Tang 2007) on the data in Figs. 6-11 at a significance level of $5 \%$. The respective statistical parameters are estimated by the sample mean $\mu$ and the sample standard deviation $\sigma$, which are noted in Figs. 6-11. Based on the average biases and standard deviations, the lognormal PDFs are superimposed on the corresponding figures for comparison.

Both Vesic's method I and the nonlinear load-transfer method underestimate the pile settlement at the intended design load. The similar results with these two methods are due to the fact that the two required loads (i.e., $Q_{\mathrm{b}}$ and $Q_{\mathrm{s}}$ ) in Vesic's method I are obtained using FB-Pier. Compared to the field load test results, the value of $Q_{\mathrm{b}}$ appears to be underestimated in FB-Pier while that of $Q_{\mathrm{s}}$ is overestimated, especially at the intended design load. It is noted that the settlement reduction due to a decrease in $Q_{\mathrm{b}}$ is larger than the settlement increment due to the same increment in $Q_{\mathrm{s}}$ with either Vesic's method or the load-transfer method. Therefore, the error in the distribution of $Q_{\mathrm{b}}$ and $Q_{\mathrm{s}}$ can lead to underestimation of pile settlement with these two methods. The values of $Q_{\mathrm{b}}$ and $Q_{\mathrm{s}}$ in Vesic's method II are obtained based on mean ratios of $Q_{\mathrm{b}} / Q$ (Table 3 ) from field tests; therefore the mean $\lambda$ values from Vesic's method II are closer to unity than those from Vesic's method I. In ad-

dition, Fleming et al.'s method overestimates the pile settlement because of the assumption that an active part of pile exists and no load reaches the lower end, resulting in a conservative pile capacity. However, the mean $\lambda$ at twice the design load with either Fleming et al.'s method or the nonlinear load-transfer method is closer to unity than that at the intended load. This can be explained by comparing the load-settlement curves from a pile-load test and from the calculation models, shown in Fig. 12. Fleming et al.'s method predicts a linear relation, thus the bias would increase with the applied load monotonically. The predicted curve from the nonlinear load-transfer method shows stronger nonlinearity than the measured curve, so the bias would decrease with the applied load.

To compare the prediction models more conveniently, the lognormal distributions of the model bias for piles founded in soil and on rock are summarized in Fig. 13. In general, the model biases are widely scattered. One possible reason is that the same relationship between the Young's modulus and the SPT " $N$ " value was used for different prediction models and load levels. This is a problem for the elastic methods in particular because the soil modulus must decrease with the strain level. The measurement errors associated with the measured settlement $S_{\mathrm{m}}$ also contribute to the discrepancy.

Table 6 summarizes the model biases (mean $\mu$ and coefficient of variation $\mathrm{COV}$ ) for the three prediction models from the statistical analysis. The mean bias of each prediction model tends to vary with the load level and the bearing stra- 
Fig. 8. Frequency diagrams of the model bias with Fleming et al.'s method for piles founded in soil: $(a)$ at the intended design load; (b) at twice the design load.
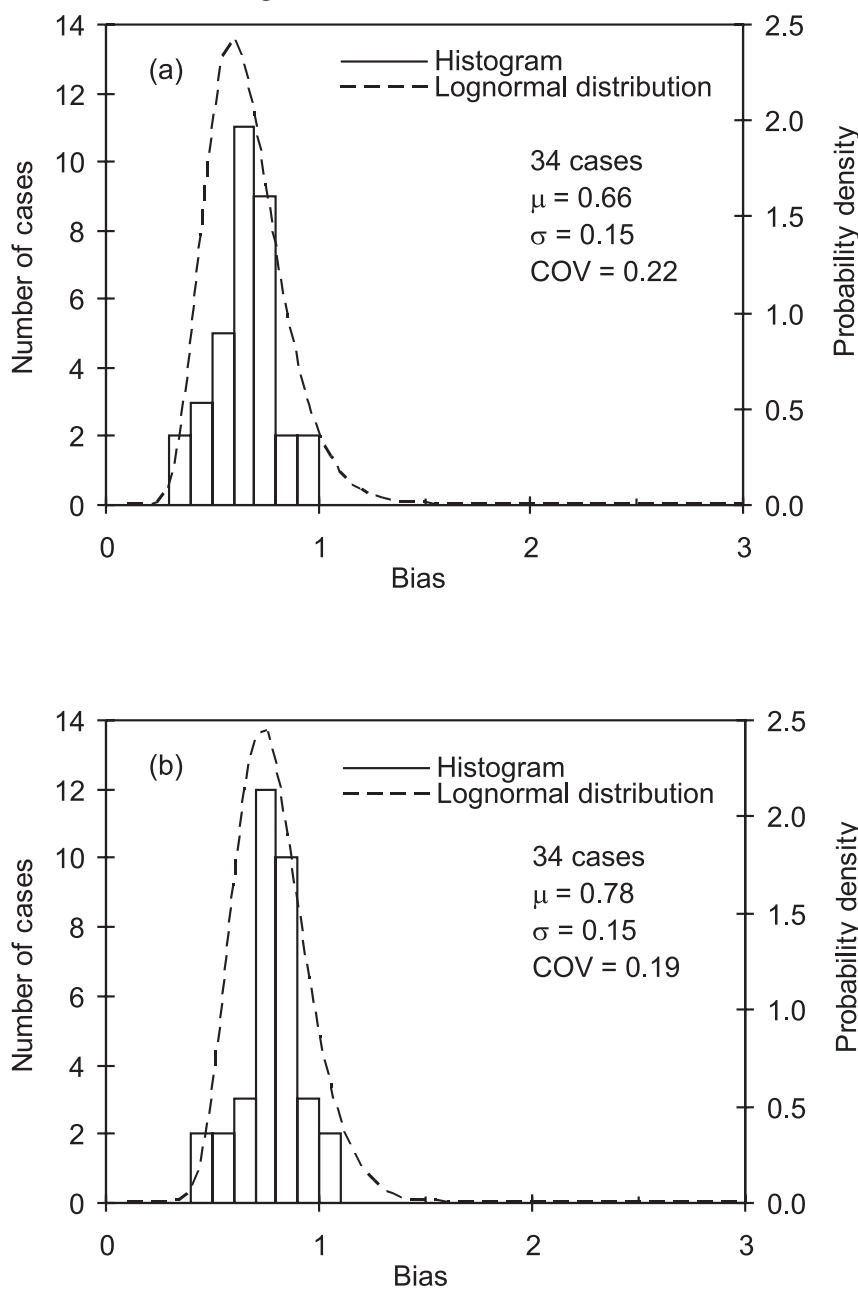

tum at the pile toe. In contrast to the mean model bias, the COV of $\lambda$ appears to fall within a narrow range of $0.19-0.28$, despite prediction models, load levels, and ground conditions. The COV values are smaller than those found by Briaud and Tucker (1988); namely, COV is between 0.35 and 1.30 for driven pile samples larger than 10 cases. One reason may be that the test piles in this study were installed in five similar reclaimed grounds following similar construction procedures, thus leading to less uncertainty in the evaluation of soil parameters and less human errors from construction workmanship. Another reason is that the average pile length in this study is much larger (45.7 m versus $12.2 \mathrm{~m}$ ), so that the variance in soil properties is reduced by the spatial averaging effect (e.g., Baecher and Christian 2003).

\section{Regression analysis of model uncertainty}

In the aforementioned statistical analysis, the model bias is studied under the intended design load or twice the design load. No analysis has been conducted for the failure load because only a few piles were loaded to failure. However, these limited available data under the failure load can be utilized for model calibration with a regression analysis. Based on the statistical results obtained, the model bias varies with
Fig. 9. Frequency diagrams of the model bias with Fleming et al.'s method for piles founded on rock: $(a)$ at the intended design load; (b) at twice the design load.
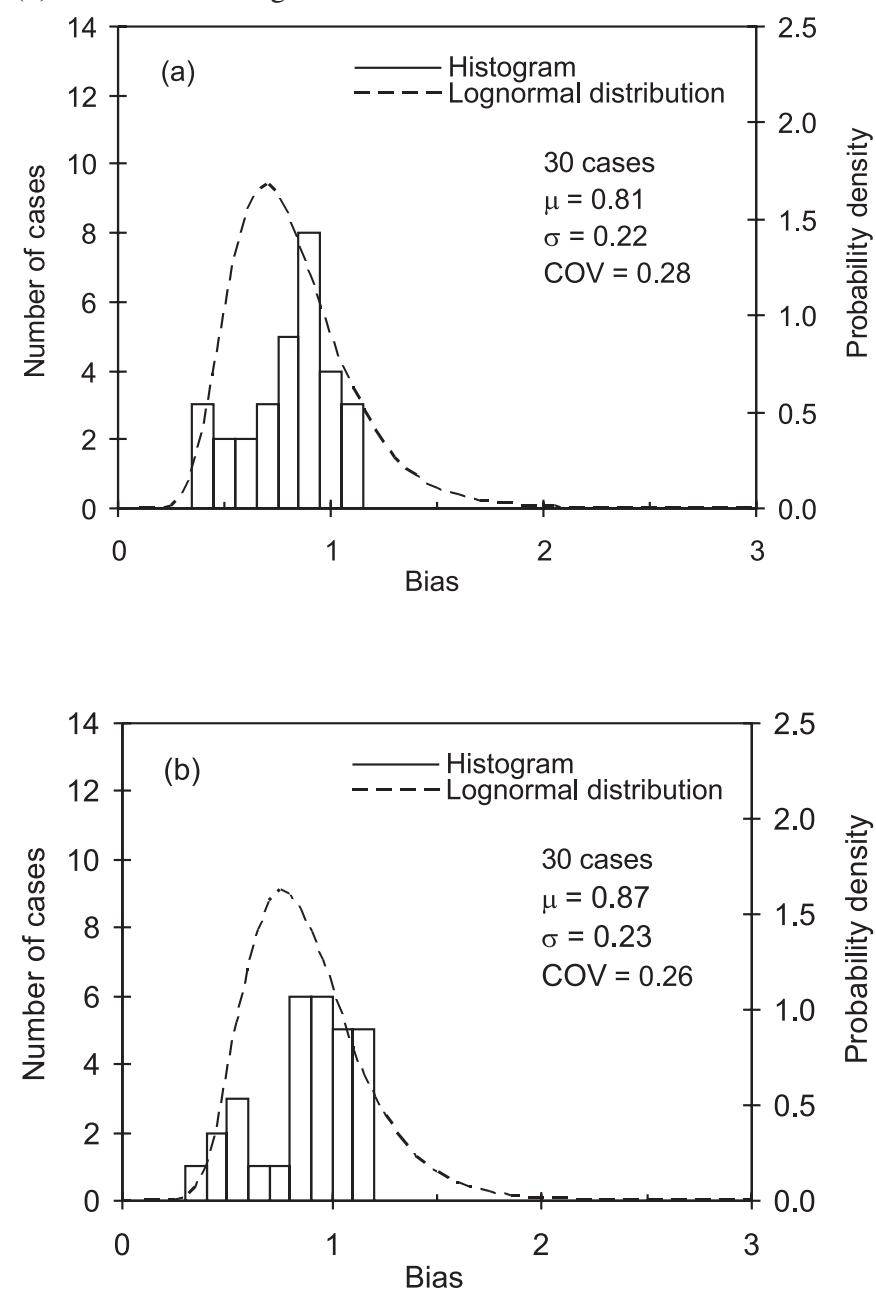

the magnitude of load or settlement. To take into account this feature, eq. [1] is rewritten as

$$
S_{\mathrm{m}}=\lambda^{\prime} S_{\mathrm{p}}^{\beta^{\prime}}
$$

where $\lambda^{\prime}$ is a general model bias, different from the definition of $\lambda$ and $\beta^{\prime}$ is a coefficient. Equation [16] can be converted to a linear regression equation

[17] $\ln \widehat{S}_{\mathrm{m}}=\beta^{\prime \prime} \ln S_{\mathrm{p}}+\ln \lambda^{\prime \prime}$

where $\ln \widehat{S}_{\mathrm{m}}$ is the estimate of $\ln \left(S_{\mathrm{m}}\right)$; and $\beta^{\prime \prime}$ and $\ln \left(\lambda^{\prime \prime}\right)$ are estimated regression coefficients. The scatter about the regression line, represented by a calibration error, $\sigma_{\ln (S \mathrm{~m}) \mid \ln (S \mathrm{p})}$, is assumed to be constant over the whole range of $\ln \left(S_{\mathrm{p}}\right)$. The least squares estimates of $\beta^{\prime \prime}$ and $\ln \left(\lambda^{\prime \prime}\right)$ have been described in textbooks (e.g., Ang and Tang 2007). It is convenient to assume that $S_{\mathrm{m}}$ and $S_{\mathrm{p}}$ are both lognormally distributed. This is consistent with the previous assumption that $\lambda$, the ratio of $S_{\mathrm{m}}$ to $S_{\mathrm{p}}$, follows a lognormal distribution. Hence, $\ln \left(S_{\mathrm{m}}\right)$ and $\ln \left(S_{\mathrm{p}}\right)$ all follow the normal distribution. Figures 14 and 15 show the relationships between $\ln \widehat{S}_{\mathrm{m}}$ and $\ln \left(S_{\mathrm{p}}\right)$ from eight samples for the three prediction models and the two pile-toe ground 
Fig. 10. Frequency diagrams of the model bias with the load-transfer method for piles founded in soil: $(a)$ at the intended design load; (b) at twice the design load.
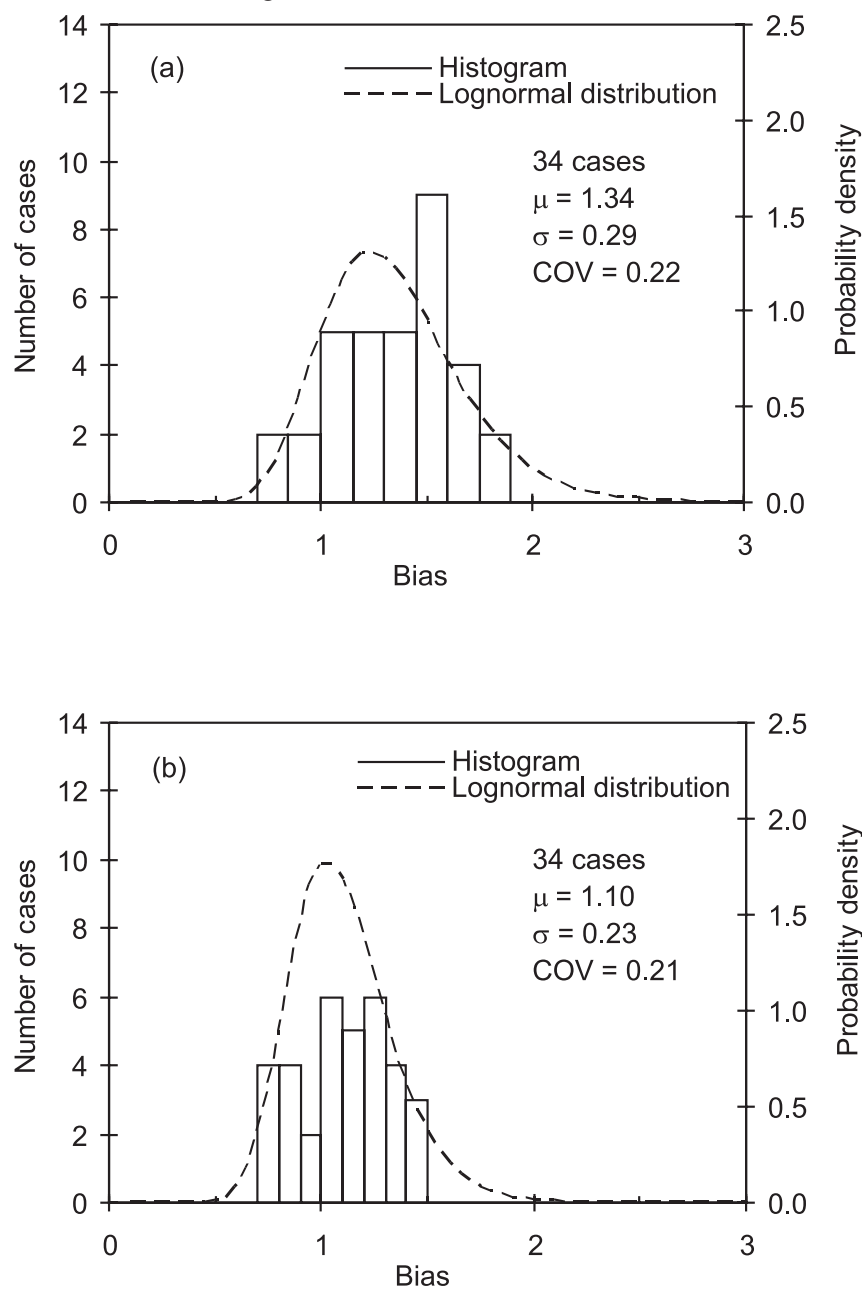

conditions. An unbiased estimate of the calibration error about the regression line, $\sigma_{\ln (S \mathrm{~m}) \ln (S p)}$, is (e.g., Ronald 1982)

$$
\sigma_{\ln S_{\mathrm{m}} \mid \ln S_{\mathrm{p}}}^{2}=\frac{n-1}{n-2}\left(s_{\ln S_{\mathrm{m}}}^{2}-\beta^{\prime \prime 2} s_{\ln S_{\mathrm{p}}}^{2}\right)
$$

where $s_{\ln (S \mathrm{~m})}$ and $s_{\ln (\mathrm{Sp})}$ are the sample standard deviations of $\ln \left(S_{\mathrm{m}}\right)$ and $\ln \left(S_{\mathrm{p}}\right)$, respectively; and $n$ is the sample size. In addition, due to a limited number of data points available in the regression analysis, the values of $\beta^{\prime \prime}$ and $\ln \left(\lambda^{\prime \prime}\right)$ may be subject to estimation errors. Therefore, the estimated mean value, $\overline{\ln S_{\mathrm{m}}}$, of $\ln \widehat{S}_{\mathrm{m}}$ is also a random variable. Assuming $\overline{\ln S_{\mathrm{m}}}$ is normally distributed, its standard deviation $\sigma_{\mathrm{ml}} \ln (\mathrm{Sp})$ at a specified site $\ln \left(S_{\mathrm{p}}\right)$ is (e.g., Ronald 1982)

[19] $\quad \sigma_{\mathrm{m} \mid \ln S_{\mathrm{p}}}^{2}=\sigma_{\ln S_{\mathrm{m}} \mid \ln S_{\mathrm{p}}}^{2}\left[\frac{1}{n}+\frac{\left(\ln S_{\mathrm{p}}-\overline{\ln S_{\mathrm{p}}}\right)^{2}}{(n-1){s_{\ln S_{\mathrm{p}}}^{2}}^{2}}\right]$

where $\overline{\ln S_{\mathrm{p}}}$ is the sample mean of $\ln \left(S_{\mathrm{p}}\right)$.

Given a specified $\ln \left(S_{\mathrm{p}}\right)$, the expectation of $\ln \widehat{S}_{\mathrm{m}}$ is (e.g., Ronald 1982)

$$
\ln \widehat{S}_{\mathrm{m}}=\overline{\ln S_{\mathrm{m}}}=\beta^{\prime \prime} \ln S_{\mathrm{p}}+\ln \lambda^{\prime \prime}
$$

Fig. 11. Frequency diagrams of the model bias with the load-transfer method for piles founded on rock: $(a)$ at the intended design load; $(b)$ at twice the design load.
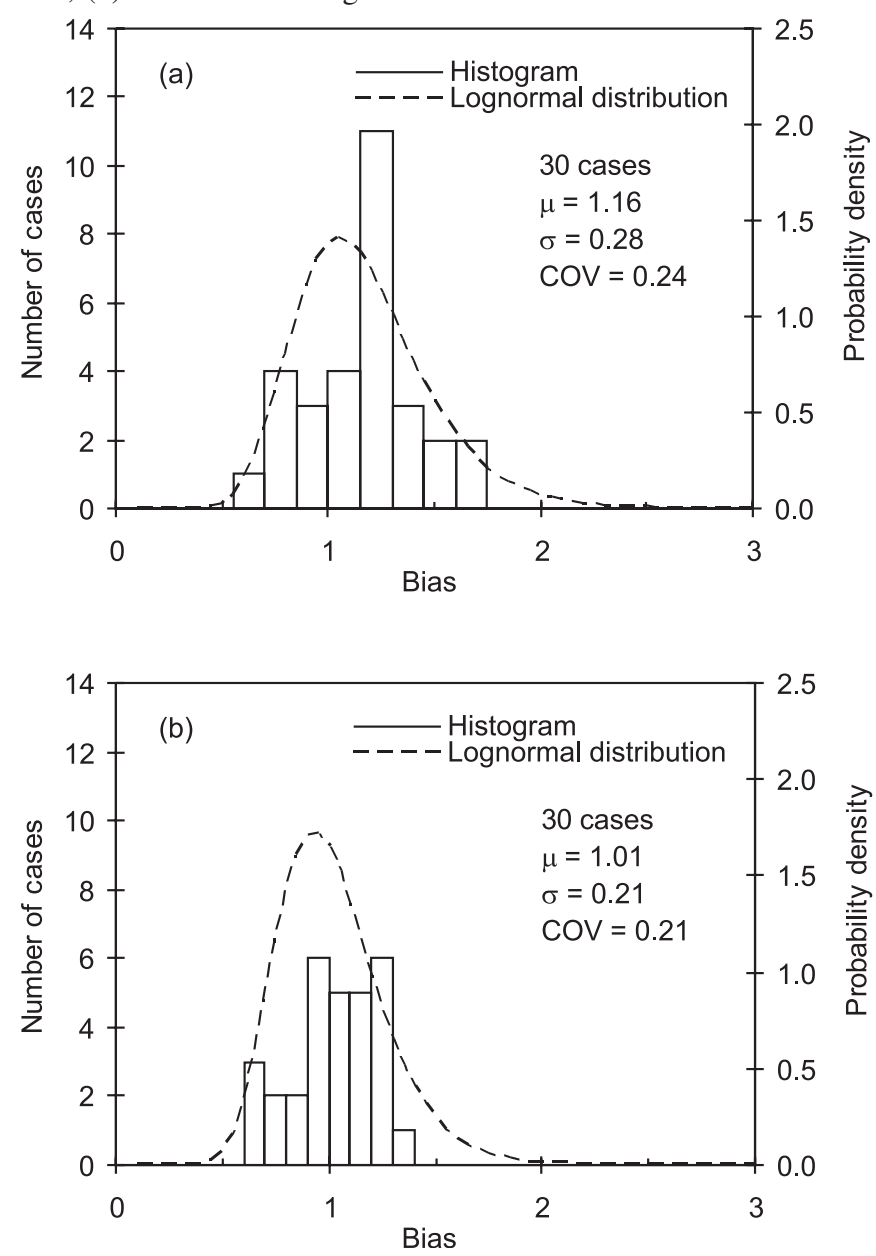

The variance of $\ln \widehat{S}_{\mathrm{m}}$, denoted by $\sigma_{\ln (S \mathrm{~m})}$, is the sum of the variance of the mean and the variance about the mean,

$$
\sigma_{\ln S_{\mathrm{m}}}^{2}=\sigma_{\mathrm{m} \mid \ln S_{\mathrm{p}}}^{2}+\sigma_{\ln S_{\mathrm{m}} \mid \ln S_{\mathrm{p}}}^{2}
$$

Finally, eq. [1], which defines the model bias factor, can be expressed as

[22] $\quad \ln \lambda=\ln S_{\mathrm{m}}-\ln S_{\mathrm{p}}$

Then the mean and variance of $\ln (\lambda), \overline{\ln \lambda}$ and $\sigma_{\ln \lambda}^{2}$, are, respectively, calculated as

$$
\overline{\ln \lambda}=\overline{\ln S_{\mathrm{m}}}-\overline{\ln S_{\mathrm{p}}}
$$

$$
\sigma_{\ln \lambda}^{2}=\sigma_{\ln S_{\mathrm{m}}}^{2}+\sigma_{\ln S_{\mathrm{p}}}^{2}-2 \rho_{\ln S_{\mathrm{m}}, \ln S_{\mathrm{p}}} \sigma_{\ln S_{\mathrm{m}}} \sigma_{\ln S_{\mathrm{p}}}
$$

where $\rho_{\ln (S \mathrm{~m}), \ln (\mathrm{Sp})}$ is the correlation coefficient between $\ln \left(S_{\mathrm{m}}\right)$ and $\ln \left(S_{\mathrm{p}}\right)$. After the mean and standard deviation of $\ln (\lambda)$ at a load level have been obtained, the mean and COV of $\lambda$ can also be obtained.

Take the settlement predictions for the piles founded in soil with Vesic's method I as an example. The values of $\overline{\ln S_{\mathrm{p}}}$ at the intended design load, twice the design load, and the failure load are $2.82,3.74$, and 4.24 , respectively; $\beta^{\prime \prime}$ and 
Fig. 12. Comparison of load-settlement curves from a pile load test and two calculation models.

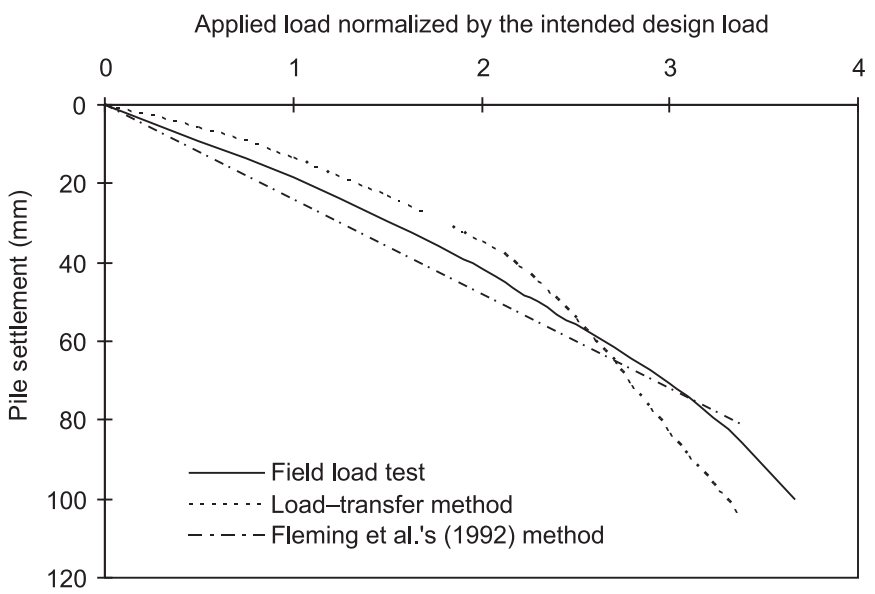

Fig. 13. Lognormal distributions of the model bias: $(a)$ for piles founded in soil; $(b)$ for piles founded on rock. $P_{\mathrm{d}}$, design load.
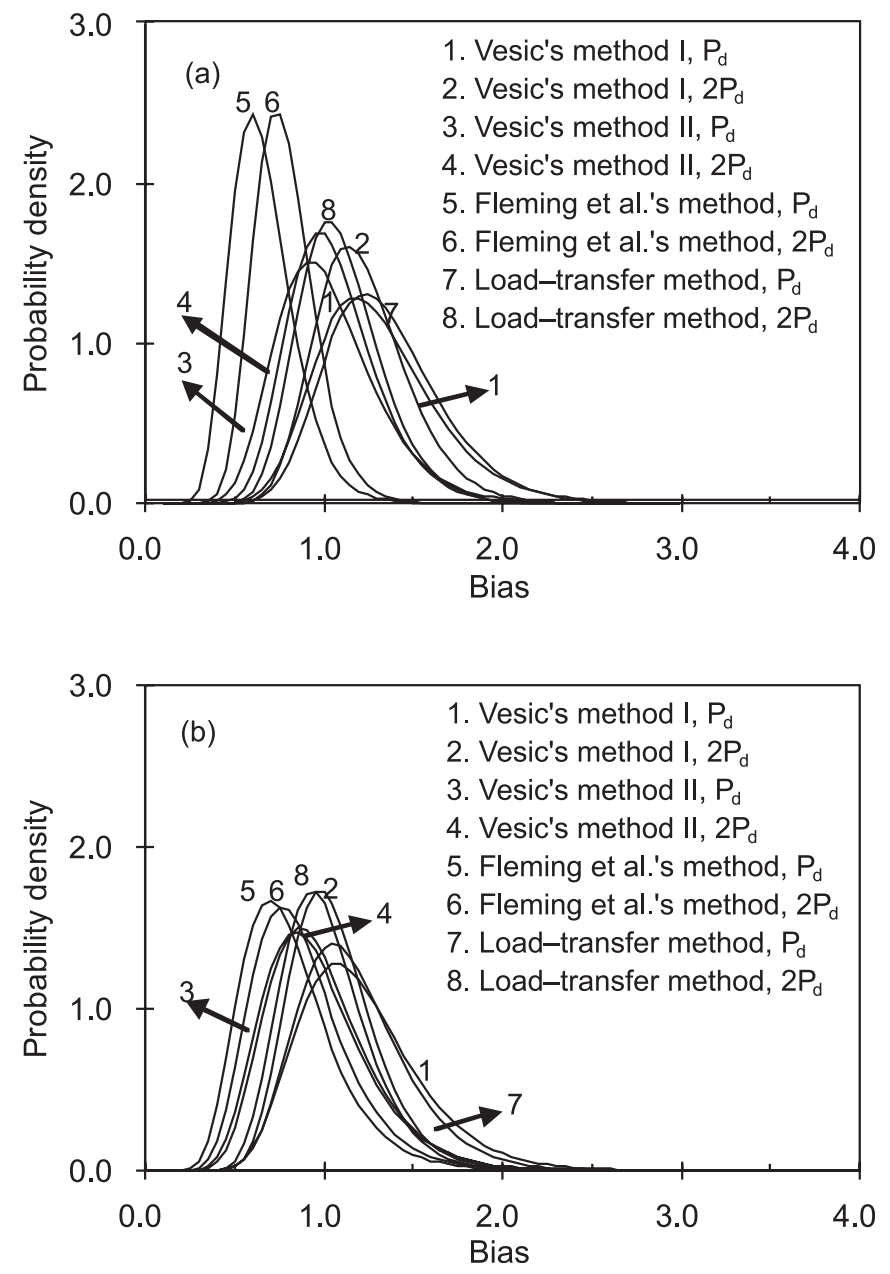

$\ln \left(\lambda^{\prime \prime}\right)$ are 0.87 and 0.61 , respectively, as shown in Fig. $14 a$. Using eq. [20], the corresponding values of $\overline{\ln S_{\mathrm{m}}}$ at the three loads are calculated as 3.06, 3.87, and 4.30, respectively. Then using eq. [23], the values of $\overline{\ln \lambda}$ at the three loads are calculated as $0.24,0.13$, and 0.06 , respectively. The values of $\sigma_{\ln (S \mathrm{~m}) \mid \ln (\mathrm{Sp})}$ at the three loads are all 0.22 ; and the values of $\sigma_{\mathrm{ml}} \ln (S \mathrm{p})$ at the three loads are 0.04, 0.03, and 0.04 , respectively. Using eq. [21], the values of $\sigma_{\ln (S \mathrm{~m})}$ at the three loads are calculated and the values are all 0.23. The values of $\sigma_{\ln (S p)}$ at the three loads are $0.11,0.09$, and 0.15 , respectively. In addition, $\rho_{\ln (S \mathrm{~m}), \ln (\mathrm{Sp})}$ can be approximated by the square root of the coefficient of determination $R^{2}$, and in this case $\rho_{\ln (S \mathrm{~m}), \ln (S \mathrm{p})}=0.91$. Therefore, using eq. [24], $\sigma_{\ln (\lambda)}$ at the three loads are calculated as $0.14,0.15$, and 0.11 , respectively. Given the values of $\overline{\ln \lambda}$ and $\sigma_{\ln (\lambda)}$, the values of the mean of $\lambda$ at the intended design load, twice the design load, and the failure load are calculated as 1.29, 1.14 , and 1.07, respectively, and their respective COV values are $0.14,0.15$, and 0.11 . The model biases of all the samples calculated from the regression analysis are summarized in Table 6.

Similar to the results of the statistical analysis, the mean bias of each prediction model tends to vary with the load level and the bearing stratum at the pile toe. It is also found that the mean biases from the statistical and regression analyses are very similar (see Table 6). This indicates that the mean of $\lambda$ can be obtained with a reasonable accuracy through a statistical analysis without the need for many test data. This lends convenience to calibrating settlement analysis models for regional practices. When limited displacement measurements vary in a large range due to, for example, large variations in pile length and design load, the regression method will be more effective.

The values of the $\mathrm{COV}$ of $\lambda$ from the regression analysis again fall within a narrow range of $0.10-0.21$, which is somewhat smaller than the values of $0.19-0.28$ obtained from the statistical analysis. This is caused by the larger samples used for the regression analysis. As found in the previous section, each statistical analysis is conducted under a particular load for 34 cases of piles founded in soils or 30 cases of piles founded on rocks. The regression analyses, on the other hand, are carried out utilizing all data at the three load levels, 82 data points for the piles founded in soil, and 77 data points for the piles founded on rock. Indeed, more information can result in less uncertainty. This is somewhat consistent with the observation by Phoon and Kulhawy (2005) that fewer data are required to estimate the mean model bias than the COV, for a given level of statistical precision. To further show the effect of the number of data, 34 data points for the piles founded in soil (8 working piles and 6 preliminary piles) and 30 data points for the piles founded on rock ( 6 working piles and 6 preliminary piles) are selected randomly and used to calibrate the nonlinear load-transfer model with the regression analysis. For the piles founded in soil, the COV values at the intended design load, twice the design load, and the failure load are calculated as $0.22,0.23$, and 0.16 , respectively, and those for the piles founded on rock are $0.21,0.19$, and 0.19 , respectively. These COV values are indeed similar to those shown in Table 6 obtained using the same amount of data through the conventional statistical analysis.

\section{Conclusions}

The information from 64 field load tests on long driven piles has been used to evaluate the performance of three settlement prediction models for single piles (i.e., Vesic's 
Table 6. Summary of model bias factors from statistical and regression analyses.

\begin{tabular}{|c|c|c|c|c|c|c|c|c|c|c|c|c|}
\hline & \multicolumn{6}{|c|}{ Piles founded in soil } & \multicolumn{6}{|c|}{ Piles founded on rock } \\
\hline \multicolumn{13}{|l|}{ Statistical analysis } \\
\hline Vesic's method I ${ }^{a}$ & 1.30 & 0.22 & 1.22 & 0.21 & - & - & 1.20 & 0.26 & 1.05 & 0.21 & - & - \\
\hline Vesic's method II ${ }^{b}$ & 1.02 & 0.23 & 1.05 & 0.20 & - & - & 0.96 & 0.27 & 0.98 & 0.25 & - & - \\
\hline \multicolumn{13}{|l|}{ Regression analysis } \\
\hline Vesic's method I & 1.29 & 0.14 & 1.14 & 0.15 & 1.07 & 0.11 & 1.19 & 0.15 & 1.03 & 0.17 & 0.96 & 0.14 \\
\hline Vesic's method II & 1.07 & 0.16 & 1.02 & 0.16 & 1.00 & 0.17 & 1.04 & 0.17 & 0.92 & 0.17 & 0.86 & 0.17 \\
\hline Fleming et al.'s method & 0.70 & 0.16 & 0.73 & 0.16 & 0.75 & 0.17 & 0.75 & 0.19 & 0.76 & 0.19 & 0.77 & 0.21 \\
\hline Load-transfer method & 1.35 & 0.17 & 1.03 & 0.14 & 0.88 & 0.10 & 1.15 & 0.19 & 0.97 & 0.17 & 0.89 & 0.13 \\
\hline
\end{tabular}

${ }^{a}$ In Vesic's method I, the values of $Q_{\mathrm{b}}$ and $Q_{\mathrm{s}}$ are determined using a nonlinear load-transfer method.

${ }^{b}$ In Vesic's method II, the values of $Q_{\mathrm{b}}$ and $Q_{\mathrm{s}}$ are based on mean ratios of $Q_{\mathrm{b}} / Q$ in Table 3 from field tests.

Fig. 14. Relationships between the mean $\ln \left(S_{\mathrm{m}}\right)$ and $\ln \left(S_{\mathrm{p}}\right)$ for piles founded in soil with: $(a)$ Vesic's method I; $(b)$ Vesic's method II; $(c)$ Fleming et al.'s method; $(d)$ the load-transfer method.
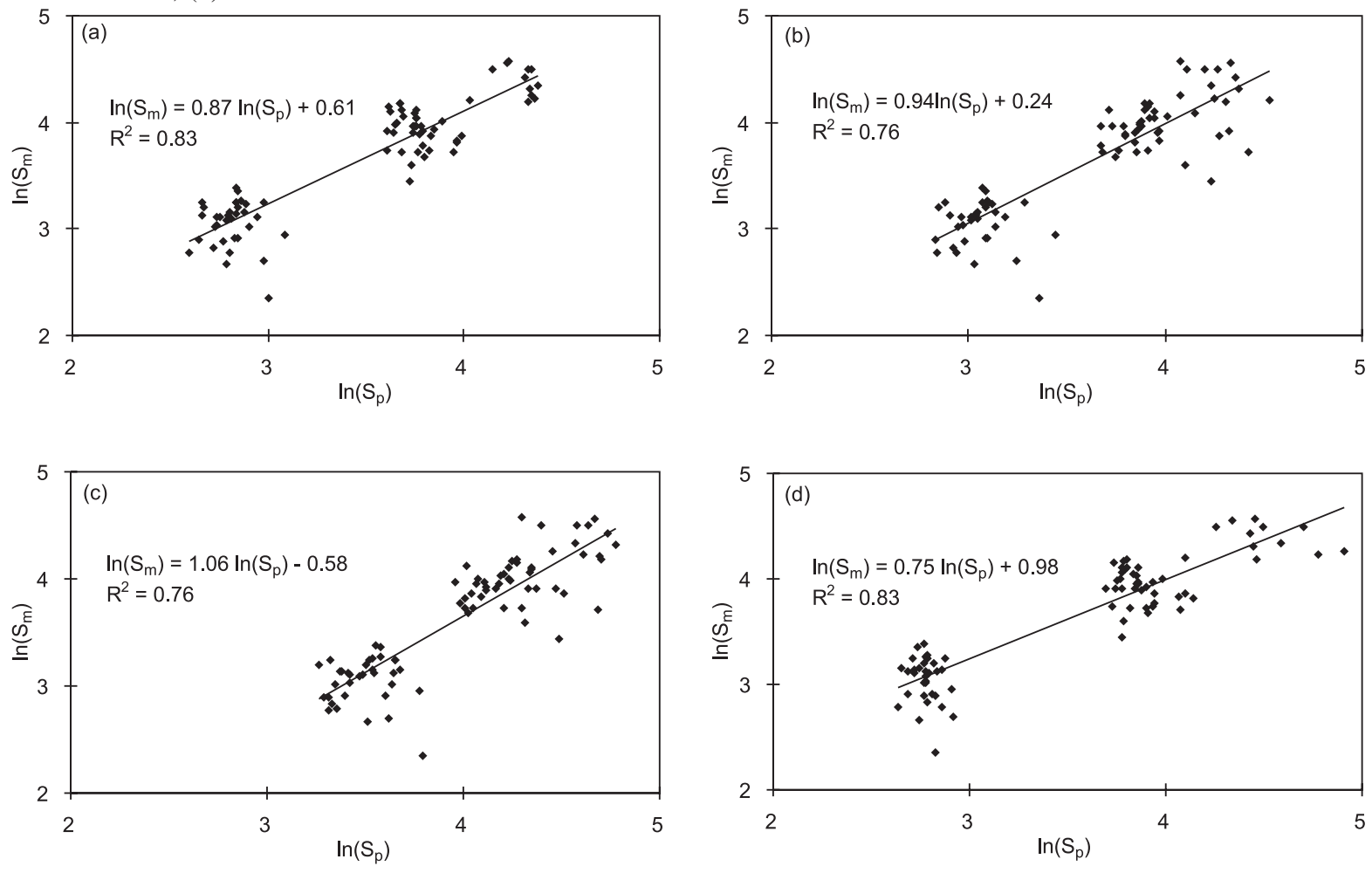

method, Fleming et al.'s method, and a nonlinear loadtransfer method), with a conventional statistical analysis and a regression analysis. Statistics of the model bias for the three prediction models at three load levels have been obtained separately for piles founded in soils and piles founded on rocks. Based on these two analyses, several conclusions can be drawn:

(1) The mean bias of each prediction model tends to vary with the load level (or magnitude of settlement) and the bearing stratum at the pile toe. The variation of the mean model bias with the load level depends on the nonlinearity of predicted load-settlement curves.

(2) The mean model bias can be obtained accurately through the conventional statistical analysis without the need for many test data. However, when limited displacement measurements vary in a large range due to large variations in pile length and design load, it would be more effective to use the regression method to calibrate settlement analysis models.

(3) The COV of model bias depends on the amount of data available, 0.19-0.28 from the conventional statistical analysis (using about 30 data points) and 0.10-0.21 from the regression analysis (using about 80 data points). The regression analysis proposed in this paper utilizes 
Fig. 15 .Relationships between the mean $\ln \left(S_{\mathrm{m}}\right)$ and $\ln \left(S_{\mathrm{p}}\right)$ for piles founded on rock with: $(a)$ Vesic's method I; $(b)$ Vesic's method II; (c) Fleming et al.'s method; $(d)$ the load-transfer method.
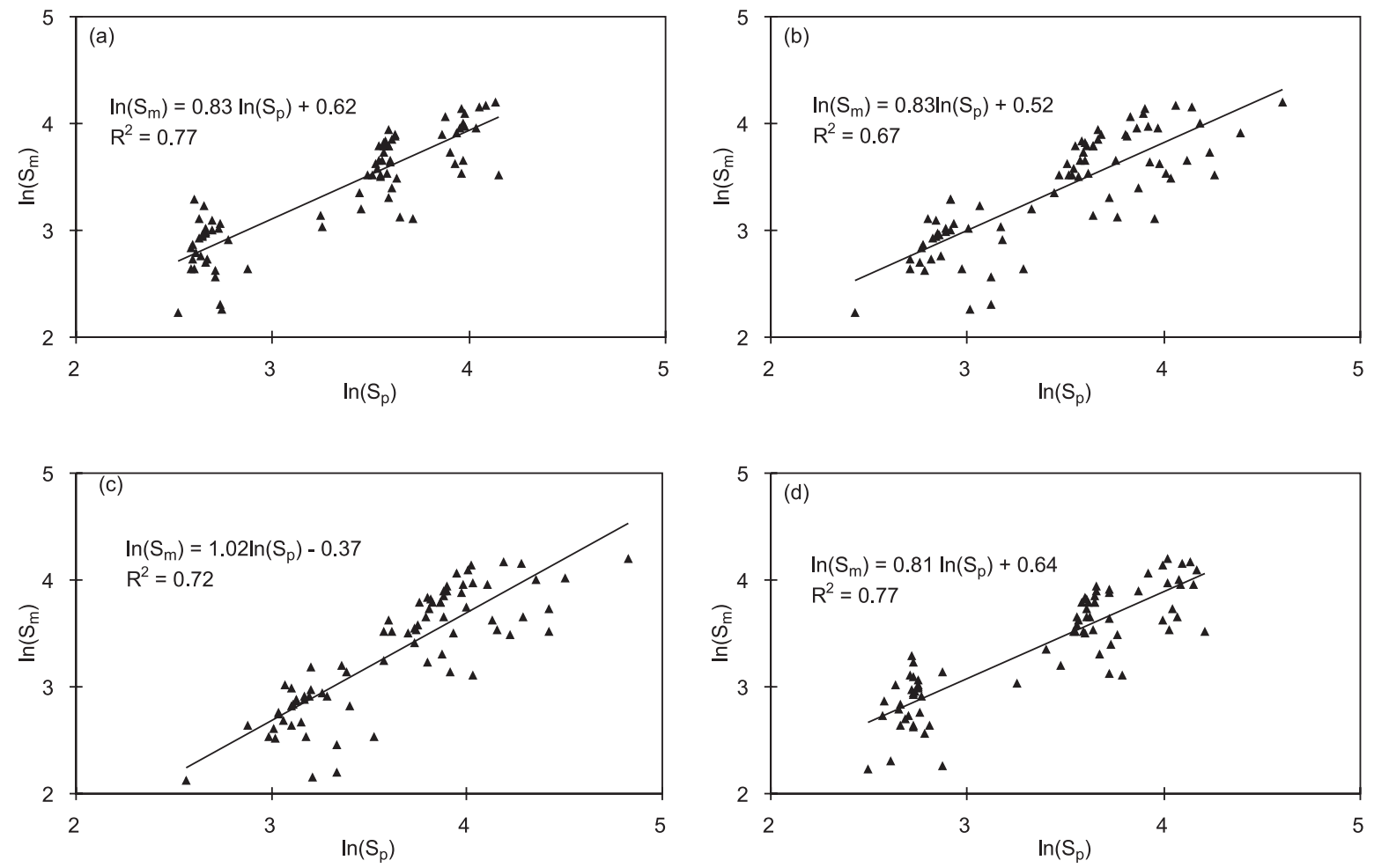

more data points; hence the COV values obtained from such analysis are smaller than those from the conventional statistical analysis.

(4) The COV of model bias appears to vary in narrow ranges. This may be caused by the fact that the test piles in this study were installed in five similar reclaimed grounds following similar construction procedures, thus involving less uncertainty in the evaluation of soil parameters and less human errors from construction workmanship.

\section{Acknowledgments}

This research was substantially supported by the Research Grants Council of the Hong Kong SAR (Project No. HKUST6126/03E).

\section{References}

Ang, A.H.-S., and Tang, W.H. 2007. Probability concepts in engineering: emphasis on applications to civil and environmental engineering, 2nd ed. John Wiley \& Sons, New York.

Baecher, G.B., and Christian, J.T. 2003. Reliability and statistics in geotechnical engineering. John Wiley \& Sons, New York.

Becker, D.E. 1996a. Eighteenth Canadian geotechnical colloquium: Limit states design for foundations. Part I. An overview of the foundation design process. Canadian Geotechnical Journal, 33: 956-983.

Becker, D.E. 1996b. Eighteenth Canadian geotechnical colloquium: Limit states design for foundations. Part II. Development for the national building code of Canada. Canadian Geotechnical Journal, 33: 984-1007.

Berezantzev, V.G., Khristoforov, V., and Golubkov, V. 1961. Load bearing capacity and deformation of piled foundations. In Proceedings of the 5th International Conference on Soil Mechanics and Foundation Engineering, Paris. Vol. 2, pp. 11-15.

Briaud, J.L., and Tucker, L.M. 1988. Measured and predicted axial response of 98 piles. Journal of the Geotechnical Engineering Division, 114: 984-1001.

BSI. 2003. The FB-Pier v3 program. Bridge Software Institute (BSI), University of Florida, Gainesville.

Buildings Department. 2000. Practice note for authorized persons and registered structural engineers 66 (PNAP66), pile foundations. Buildings Department, Hong Kong.

Coyle, H.M., and Reese, L.C. 1966. Load transfer for axially loaded piles in clay. Journal of the Soil Mechanics and Foundations Division, 92: 1-26.

Der Kiureghian, A. 1990. Bayesian analysis of model uncertainty in structural reliability. In Proceedings of 3rd IFIP WG7.5 Working Conference on Reliability and Optimization of Structural System, Berkeley, Calif., 26-28 March 1990. Edited by A. Der Kiureghian and P. Thoft-Christensen, Springer-Verlag, Berlin, Germany. pp. 211-221.

Fenton, G.A., and Griffiths, D.V. 2005. Three-dimensional probabilistic foundation settlement. Journal of Geotechnical and Geoenvironmental Engineering, 131: 232-239. doi:10.1061/ (ASCE)1090-0241(2005)131:2(232).

Fenton, G.A., Griffiths, D.V., and Cavers, W. 2005. Resistance factors for settlement design. Canadian Geotechnical Journal, 42: 1422-1436. doi:10.1139/t05-053.

Finno, R.J., Achille, J., Chen, H.C., Cosmao, T., Park, J.B., Picard, J.N., Smith, D.L., and Williams, G.P. 1989. Summary of pile capacity predictions and comparison with observed behavior. Geotechnical Special Publication, No. 23, ASCE, New York. pp. 356-385. 
Fleming, W.G.K., Weltman, A.J., Randolph, M.F., and Elson, W.K. 1992. Piling engineering. John Wiley \& Sons, New York.

GEO. 1993. Guide to retaining wall design. Geotechnical Engineering Office, Civil Engineering Department, Hong Kong.

GEO. 2006. Foundation design and construction. Geotechnical Engineering Office, Civil Engineering Department, Hong Kong.

Goodman, R.E. 1980. Introduction to rock mechanics. John Wiley \& Sons, New York.

Hong Kong Housing Authority. 2000. Foundation works specification: piling and footing. Specification Library 2000 Edition, Hong Kong.

Jardine, R.J., Potts, D.M., Fourie, A.B., and Burland, J.B. 1986. Studies of the influence on non-linear stress-strain characteristics in soil-structure interaction. Géotechnique, 36: 377-396.

McVay, M.C., O'Brien, M., Townsend, F.C., Bloomquist, D.G., and Caliendo, J.A. 1989. Numerical analysis of vertically loaded pile groups. In Proceedings of Foundation Engineering Congress, ASCE, Northwestern University, Ill. 25-29 June 1989. Edited by F.H. Kulhawy, ASCE, New York, pp. 675-690.

Paikowsky, S.G. 2002. Load and resistance factor design (LRFD) for deep foundations. In Foundation Design Codes - Proceedings of IWS Kamakura 2002. Edited by Y. Honjo, O, Kusakabe, K. Matsui, M. Kouda, and G. Pokharel. A. A. Balkema, Rotterdam. pp. 59-94.

Paikowsky, S.G., and Lu, Y. 2006. Establishing serviceability limit state in the design of bridge foundations. In Foundation analysis and design-innovative methods, Geotechnical Special Publication No. 153, ASCE, Reston. pp. 49-58.

Peck, G.M. 1969. The rational design of large diameter bored piles founded on rock. In Proceedings of Rock Mechanics Symposium, Institution of Civil Engineers, Sydney. pp. 48-51.

Phoon, K.K., and Kulhawy, F.H. 1999. Characterization of geotechnical variability. Canadian Geotechnical Journal, 36: 612624. doi:10.1139/cgj-36-4-612.

Phoon, K.K., and Kulhawy, F.H. 2005. Characterisation of model uncertainties for laterally loaded rigid drilled shafts. Géotechnique, 55: 45-54.

Poulos, H.G., and Davis, E.H. 1980. Pile foundation analysis and design. John Wiley \& Sons, New York.

Randolph, M.F., and Wroth, C.P. 1978. Analyses of deformation of vertically loaded piles. Journal of the Geotechnical Engineering Division, 104: 1465-1488.

Ronald, E.W. 1982. Introduction to statistics, 3rd ed. Macmillan, New York.

Schmertmann, J.H. 1975. Measurement of in situ shear strength. In Proceedings of the ASCE Specialty Conference on In Situ Measurement of Soil Properties, Raleigh. Vol. 2, pp. 57-138.

Shahin, M.A., Jaksa, M.B., and Maier, H.R. 2005. Neural network based stochastic design charts for settlement prediction. Canadian Geotechnical Journal, 42: 110-120. doi:10.1139/t04-096.

Shek, M.P. 2005. Driveability and performance of long driven piles founded in saprolites. MPhil thesis. The Hong Kong University of Science and Technology, Hong Kong.

Vesic, A.S. 1977. Design of pile foundations. National Cooperative Highway Research Program Synthesis of Practice No. 42, Transportation Research Board, Washington, D.C.

Zhang, L.M., Tang, W.H., and Ng, C.W.W. 2001. Reliability of axially loaded driven pile groups. Journal of Geotechnical and Geoenvironmental Engineering, 127: 1051-1060. doi:10.1061/ (ASCE)1090-0241(2001)127:12(1051).

Zhang, L.M., Tang, W.H., Zhang, L.L., and Zheng, J.G. 2004. Reducing uncertainty of prediction from empirical correlations. Journal of Geotechnical and Geoenvironmental Engineering, 130: 526-534. doi:10.1061/(ASCE)1090-0241(2004)130:5(526).
Zhang, L.M., Li, D.Q., and Tang, W.H. 2005. Reliability of bored pile foundations considering bias in failure criteria. Canadian Geotechnical Journal, 42: 1086-1093. doi:10.1139/t05-044.

Zhang, L.M., Shek, M.P., Pang, W.H., and Pang, C.F. 2006. Knowledge-based pile design using a comprehensive database. Geotechnical Engineering. Proceedings of the Institution of Civil Engineers, 159(GE3): 177-185.

\section{List of symbols}

$A_{\mathrm{b}}$ area of pile base

$A_{\mathrm{p}}$ area of pile cross section

$D$ pile width or diameter

$E_{\text {ave }}$ average Young's modulus of the soil along the pile shaft

$E_{\mathrm{f}}$ field modulus of deformation of rock

$E_{1}$ laboratory modulus of deformation of rock

$E_{\mathrm{p}}$ modulus of elasticity of pile material

$E_{\mathrm{sb}}$ modulus of elasticity of the soil near the pile toe

$E_{\mathrm{s} i}$ Young's modulus of the $i$ th soil layer

$E_{\mathrm{Ss}}$ modulus of elasticity of the soil along the pile shaft

$G_{\text {ave }}$ average shear modulus of the soil along the pile shaft

$G_{\mathrm{b}}$ shear modulus of the soil beneath the pile toe

$G_{\text {is }}$ initial shear modulus of the soil along the pile shaft

$G_{\mathrm{ib}}$ initial shear modulus of the soil near the pile toe

$G_{\mathrm{L}}$ shear modulus of the soil at depth $L$

$G_{L}^{\prime}$ soil shear modulus at the bottom of the active pile length

$I_{\mathrm{b}}, I_{\mathrm{S}}$ influence factors

$H$ depth of the pile cross-section

$K_{\mathrm{S}}$ coefficient of horizontal earth pressure on pile

$\ln \widehat{S}_{\mathrm{m}}$ estimate of $\ln \left(S_{\mathrm{m}}\right)$

$\overline{\ln S_{\mathrm{m}}}$ estimated mean value of $\ln \widehat{S}_{\mathrm{m}}$

$\overline{\ln S_{\mathrm{p}}}$ sample mean of $\ln \left(S_{\mathrm{p}}\right)$

$\overline{\ln \lambda}, \sigma_{\ln \lambda}^{2}$ mean and variance of $\ln (\lambda)$

$L$ pile length

$L_{\mathrm{ac}}$ active pile length

$L_{i}$ thickness of the $i$ th soil layer

$L_{\mathrm{w}}$ water level

$N$ sample size

$N_{\mathrm{q}}$ bearing capacity factor

$N_{\varphi}$ a factor related to the friction angle of rock

$P_{\mathrm{d}}$ design load

$P$ pile perimeter

$q_{\mathrm{b}}$ load per unit area at the pile toe

$q_{\mathrm{p}}$ ultimate unit toe resistance

$q_{\text {uf }}$ field unconfined compression strength of rock

$q_{\mathrm{ul}}$ laboratory unconfined compression strength

$Q$ total load applied on pile

$Q_{\mathrm{b}}$ load carried at the pile toe

$Q_{\mathrm{f}}$ ultimate toe resistance

$Q_{\text {s }}$ load carried by frictional resistance

$r_{0}$ radius of the pile

$r_{\mathrm{b}}$ radius of the pile toe

$r_{\mathrm{m}}$ radius out from the pile shaft where axial loading effects on soil are negligible

$R^{2}$ coefficient of determination for the regression line

$S_{\ln (S \mathrm{~m})}, S_{\ln (S \mathrm{p})}$ sample standard deviations of $\ln \left(S_{\mathrm{m}}\right)$ and $\ln \left(S_{\mathrm{p}}\right)$

$S$ total pile settlement

$S_{1}$ elastic compression of pile

$S_{2}$ settlement of pile caused by the load at the pile toe

$S_{3}$ settlement of pile caused by the load transmitted along the pile shaft

$S_{\mathrm{m}}$ measured settlement

$S_{\mathrm{p}}$ predicted settlement 
$\beta^{\prime \prime}, \ln \left(\lambda^{\prime \prime}\right)$ estimated regression coefficients

$\gamma$ total unit weight

$\delta_{\mathrm{s}}$ angle of friction at pile-soil interface

$\lambda$ model bias

$\lambda_{\mathrm{p}}$ pile stiffness ratio

$\lambda^{\prime}$ general model bias

$\phi$ internal friction angle

$v$ Poisson's ratio

$\xi$ coefficient for elastic pile compression calculation $\rho_{\ln (S \mathrm{~m}), \ln (S \mathrm{p})}$ correlation coefficient between $\ln \left(S_{\mathrm{m}}\right)$ and $\ln \left(S_{\mathrm{p}}\right)$

$\sigma_{\text {ave }}^{\prime}$ average effective stress of a stratum

$\sigma_{\mathrm{v} 0}$ effective stress at pile toe

$\sigma_{\ln (S m)}$ variance of $\ln \widehat{S}_{\mathrm{m}}$

$\sigma_{\ln (S \mathrm{~m}) \mid} \ln (S \mathrm{p})$ calibration error about the regression line

$\sigma_{\mathrm{ml}} \ln (S \mathrm{p}) \quad$ standard deviation of $\overline{\ln S_{\mathrm{m}}}$ at a specified site $\ln \left(S_{\mathrm{p}}\right)$

$\tau_{0}$ shear stress being transferred to the soil for a given settlement

$\tau_{\mathrm{f}}$ ultimate shear stress transferred to the soil 